\title{
The Attack and Defence of Fleets
}

\section{Captain P. H. Colomb R.N.}

To cite this article: Captain P. H. Colomb R.N. (1871) The Attack and Defence of Fleets, Royal United Services Institution. Journal, 15:64, 405-437, DOI: 10.1080/03071847109425419

To link to this article: http://dx.doi.org/10.1080/03071847109425419

$$
\text { 曲 Published online: } 11 \text { Sep } 2009 .
$$

Submit your article to this journal

Џll Article views: 3

Q View related articles $\longleftarrow$ 


\section{Everenimg atleting.}

Monday, April 3rd, 1871. REAR-ADMmal TIE RIGHT HON. LORD FREDERICK KERR,
in the Chair.

NAMIES of MIEJEBERS who joined the Institution betwecn the 20th Mfarch and 3rd April, 1871,

LIFE.

Bromn, James, Licut. R.s.'.

Irale, I.onsdale, A., Capt. R.E.

Kerr, C. R., Ensign 102nd Rert.

ANNUAL.

Craufurd, If. R. G., Licut. R.A.

Nocl, G. II., Licut. R.N.

Jones, Mainmaring, Lusign Ion. Art. Co.

Lyttleton, Mon. N. G., Lt. Rifle Brig.

Sraine, I. T., Lient. Rifle Brigade.

Malcolm, G. J., Capt. R.N.

Ross, J. C., Licut. K.iv., Bengal.

\section{IHE ATTACK AND DEFENCE OF FLEETS.}

\section{By Captain P. H. Colours, R.N.}

I.

The Grarrarax: 1 call upon Captain Golomb to address the meeting on the subject of the " $\Lambda$ ttack and Defence of Fleets." But previous to Captain Colomb's commencing, I wish to call attention to a notice that has been put up. In theso societies it is necessary that wo should observe the rules that are laid down for our guidance; and one of the rules here is, that in the discussion after the lecture, ten minutes only can be allowed to each spealer. I, therefore, hopo that gentlemen who may mish to address the meeting, will confine their remarks within that time.

Captain CoLOsB: The subject I have undertaken to illustrate in tonight's paper is one of extremo importance at the present juncturc. It is not only desirable that we should find ourselves prepared with some definite views on naval warfare in the open sea, when carried out with the ships and weapons now at our command, but it must never be forgotten that tho views we may form will, and do, actually gorern the nature of the designs produced by our arelitects, and the disposition of guns and other weapons on thicir tloating carriages. It would thercfore be a culpable error for any one treating of the attrek and defence of flcets, to confine himself to questions of manourring merely, as though ships were, like men, of an unchangeable type. Triters of the past on the subject of naval tactics, such as De Mlorogues, Père Hoste, and Clarke, if Eldin, might well bo excused if thoy thus treated their science. But 
such a method is no longer permissible. Writers of our age, who assume in some sense to lead opinion, must remember that we stand at the cross roads of naral warfare; we aro no longer hedged in by impassable barricrs on the smooth lighway of progress. Manj roads aro open to us, and wo hare to nake a selcction, guided by a not much better trail than the Indian hunter finds in lis forests. I am the moro anxious to press this point forward, as I bolicre we are not sufficiently alive to the fact that the current view on the attack and defence of flects is the foundation of all design in naval matericl. I say I think we are not sufficiently alive to this fact, becauso I cannot believe, were it otherwise, that wo should rest content with certain instinctive ideas on the subject of future naral war, and make almost no attempt to formulate our instincts, and separate where possible tho chaff from the wheat. If I were to make the assertion that the designs of our ships arise more out of instinct and tradition than out of any comprehension of how they aro liablo to attack, and how they aro capable of defence, I should at first raise a feeling of incredulous surprise in the minds of my audience. Yet I do make the assertion, and think that a few sentences in explanation will entirely remore the incredulity, while they will strengthen the surprise. Consider for a moment how jou could rebut my assertion. . What sort of arguments would sou use, and what sort of facts rould you produce to sustain the counter-proposition that our ships were designed to deliver certain specified and approred attacks, and to offer certain distinct resistances? Yon wonld be constrained to. rely on tho general proposition that the ships were designed to use their guns, and porhaps their rams for attack; and their armour for defenco against guns. Beyoud this you could not go; and you will observe that it is a veiy small step. 'The gun and the ram are presented to jour viow as possible weapons, because they aro both traditional; you cannot build a war ship excopt on the supposition that she is to use both or either of them. On the other hand your instinctive desire for protection from shot las giren you armour plating. In what respect you have adranced bejond instinct and tradition can only be proved by ascertaining whether you appreciate the relativo ralues of the two weapons provided, and have designed your ship in agrecment with that relation. Tako an illustration from the infantry soldier, which is temptingly apposite to the case in hand. He has tro meapons, his riflo and his bajonet. Their relative raluo is established and known, and no projector would be mad enough to sacrifice one iota of the known value of the rifle to the problematical ralue of the bajonet. But who can say of any ship in our Nary in which the two.weapons are combined, that her gun-power is properly sacrificed to assist lier ram as the superior weapon, or that her ram-power is judiciously curtailed to admit of increased ordnance? For clearness of expression, I am leaving out of consideration the third weapon-the offensice torpedo-which it will be necessary hereafter to treat distinctly; but is not my assertion, cren in the caso of any single ship called upon to attack, or defend herself from any other single ship, quite borne out by the elementary considerations I have adverted to ?

If wo go a step beyond tho single ship, and glance at the preparation 
mado in our ships for combined attack, or combined defence, we shall light upon a complete abnegation of any such.idea.

But returning to the single ship, and aroiding the confusion of tho donble weapon in the same ship, think what is ascertained as the best method of carrying ordnanco? Is the "Monarch" or tho "Hercules" the nore powerful ship? or would the 5,000 tons of the "MIonarch," and her four 25-ton guns, fall rictims to the attack of fivo lightly clad ships of 1,000 tons, cacl carrsing a single 25-ton gun?

'then if the ram be alono considered, what aro the relative values of specd and turning powers for attack upon a willing adrersary, or for compulsory defence? May speed be judiciously sacrificed to turning powers, and to what extent? Or must speed bo sccured at all hazards, and turning powers only considered aftermards?

If wo are not depending on tradition and instinct, then categorical answers are forthcoming to all these queries. But if no such things arc extant-which is unfortunately true-and if besides, very little effort is exerted in the attainment of true solutions, then my position remains unassailed and unassailable.

Now, what I want jou to observe in all this is, that whilo wo are very apt to think that the shis and weapons presented to the naral Officer for his uses in a complete state, cause him to take particular. views of attack and defence, and give rise to his speculations on tho subject; yet the converse of this is the case. He first forms viers of attack and defence, and these find expression aftericards in material products. It is the abstract gun, ram, and torpedo, which form his original ideal of warfarc; the concrete weapons do no more than modify views already outlined in his mind. If his original ideal is crude, unthought ont, abore all, if there are dirersities of ideal, the results in a material form will give rise to rague uncertaintics, and endless discus. sions, such as those by which we find ourselves now surrounded.

It will be secn, therefore, that from my point of view I could offer sou no more important or comprehensive question than that I havo chosen as the title of $\mathrm{my}$ paper.

I had no sooner plotted out what I thought should be said on an occasion liko the present, the facts it would be necessary to put foryard, the deductions it would be proper to draw, and the general line of treatment it would be desirable to pursue, than I became overwhelmed with the magnitude of the task before me. "For just observe for a moment what a paper on "the attack and defence of flects" might be expected to deal with. Think in what aspects a professional audienco might justly call upon me to place the subject before them.

There would first be the theory of the matter. You rould expect me to set out the theoretical relative ralues of the gun, the ram, and the torpedo, as offensire or defensire menpons. Encl must, therefore, be carefully and separately considered, and then considered afresh in their relation to each other.

It would next be proper to look at the state of naval opinion at lome and abroad on this question of relative value, and to noto how it might coincide or differ with the conclusions independently arrired at. The ultimate conclusions, whaterer thes were, ought then to be applied 
to the combat between single ships of existing types, and from the whole discussion should be drawn tho decluction as to how present ships fulfil the idenl requirements so far.

I do not think I exaggerate when I say that any discussion of the attack and defence of a flect is absolutely valueless prior to the analysis I have sketched ont, but it is apparent that analysis would fully occupy the limits of a single paper.

The next step in the enquiry would be the theoretical methods of making a flect mobilo and tlexible under the control of an Admiral. The state of naval opinion at lome and abroad should bo applied here, as it was to the values of the weapons, and compared with tho facts.

After this, fou might fairly call upon me to consider the offensire and defensive features of the various formations proposed or possible, and of the morements by which they aro obtaincd; and here it would bo necessary again to glance at tho state of naval opinion on this head. Then, and not till then, should we be in a condition to place ourselves in the position of a flect attacking, or a flect attacked, and so decluce the rules within which we must act to givo tho greatest rigour to our attach, and the greatest solidity to our defence.

In facing these conditions which scemed to me unavoidable, I had to consider how I should meet them. I might tonch very lightly and inefficiently on each branch of the subject, and compress the whole of it so greatly as not to extend the limit of time allowed, but I felt it was not just to so great a subject, so very casually studied, to treat it in that cursory way. If I had had any further doubts about it, they were fully resolred when I found that I liad written enougl for an hour and lialf's readiug, and had not so much as touched the flect question at all!

Therefore, to my great regret, I come before jou to-night under the false preteuce of a misnomer in title, "Tho Attack and Defence of Flects," lias dwindled to the attack and defence of single ships, and if I receive your censure at the outsct for $\mathrm{my}$ acknowledged short comings, I shall hope to modify it by showing at the conclusiou that I was a helpless instrument in the hands of my facts.

IVithout further preface, then I shall proceed with the examination of guns, rams, and torpedoes, in the order and with the oljects I havo pointed out.

Guns.

In my paper on "Modern Naral Tactics" read here fire Jears ago, seagoing turret-ships were not, and the discussion of the gun-power of a flect was necessarily confined to broadside ships, whose fire corered an arc of three points before and abaft the beam.

In my "Lessons from Lissa," also read here in 1867, the "Bellcrophon" was our representative slip, and the calculations used to illustrato gunpower were drawn from her capabilities.

Tho "MInarch" is now our representatice sea-going ironelad, and she must do duty as our typical ship. In so using her, I am not prejudging the great cause of turret versus broadside, on the contrary, my 
opening remarks show that I do not mean to take the "MIonarch" as a perfect slip, and consider how a fleet of such ships can be best cmployed. I take the " MLonarch" as my ideal, in order that I may not find myself dealing with an impossible type, and because the "Monarch" cmbodies in the highest degreo tho principle of construction and armament most opposed to that found officient in former naral wars.

All round fire is unquestionably the object to which so much is sacrificed in the "Monarch," nud if 'I wero to take a ship like the "Hercules" as my representative, I should find the struggle after allround fire just as prominent there, but carried out under a smaller departure from old methods of construction. Tho "Mlonarch" has tho fowest and heaviest guns of any sea-going ship in tho Navy, and sho exercises her. gun-poner over a larger are than any other. She is the cmbodiment of the idea that the gun is the dccisive weapon at sea, to which all others must give place, and that this weapon is most powerful when mounted in limited numbers, of the greatest size, and with the largest are of training.

The question I propounded four jears ago in my paper on the battle of Lissa was, "whether the gun was adrancing or receding in power as a naral weapon ?" The illustration was whether the guns of the "Bellerophon," as ayainst a "Bellerophon," were more or less powerful than the guns of a 90 -gun ship against another of her class before the adrent of ironclads. The question to-night is, so far as ganis are concerned, the same, but carried a stage further. "Has the "gun-power of tho 'MIonarch,' as against a 'Mlonarch,' adranced or' " receded from the position held by the guns of tho "Bellerophon" " against a sister ship ?"

In the discassion of the carlier stage, I endeavonred to show by an analysis of the forces at the battle of Lissa, how enormously the gun was falling back before the increasing work it was called upon to do. IIy comparison was in the first instance, that, nuder the old system of building and arming ships, cach Italian gun would have had only fifty tons of material to destroy in completing the annibilation of the Austrian flect; and cach Austrian gun would have had only 93 tons of Italian shipping opposed to it. With the new methods of building and armament, however, under which the Flects actnally met, each Italian gun liad 260 tons of material to destroy, and each Austrian gun 432 tons : that is to say, unless the guns at the battle of Lissa conld give shot for shot of tho light guns used in former times, and each shot were about five times as destructive, the gun had receded from its place as a naral weapon. I then proceeded to show, that so far from modern guns keeping up shot for shot with their prototypes, their specd of fire was vers materially reduced, and that one round in two minutes was as rapid a fire as could be expected.

A Iissa ship opposed to another, gare an average of 346 tons of destructive work.

A "Bellerophon" opposed to a "Bellerophon" gires 600 tons of destructive work to be done by each gun. $\Lambda$ "MIonarch" opposed to a "Monarch" gives no less than 1,275 tons of work. If, therefore, I had reason in pointing to the recession of tho gun from its placo as a 
weapon, by tho results of tho battle of Lissa, what am I to say when I find it has now receded three times as far as it had then?

I imagined that guns, then, supposing them to give shot for shot with the old ones, must be firo times as powcrful to retain their places. Now, on the same principle, I must imagine the "Mounrch's" guns to be about twice as powerful as the "Bellerophon's," or about fifteen times as pomerful as tho old smooth bores, in order to keep their placo in tho race.

If the "Bellerophon's" plating bo considered to hare a resisting power of 36 , the "Monarch" has a resisting power of 49 , which again tells against tho guns. But, on the other hand, tho "Monarch's" guns exert a striking force of 5,000 foot-tons at 1,000 5ards, in licu of 2,400 foot-tons which tho "Belleroplion's" guns exert at the samo range. Making a proportion, wo find that tho power of resistance has increased in the ratio of 1 to $1 \cdot 3$, and of attack in the proportion of 1 to 2 . The net result in farour of the guns is $0 \cdot 7$, and, consequently, tho net recession of the gunpower since the "Bellerophon's" time, is in the proportion of 1 to 1.3 .

Now, it scems that a shot from the 25-ton gun, fired at a range of 700 yards, baring on impact an cnorgy. of 170 foot-tons per inch of shot's circumference, fails to penetrate the "Hercules" "target.

The "Hercules" "target is, in resisting forco to the "MIonarch," as 64 to 49 , and the energy of the "Monarch's" shot, at 1,000 jards, is 137 foot-tons per inch of circumference. The proportion between the figures show that the resisting powers of the "Nlonarch's" side agaiust her guns at 1,000 yards are as nearly as possible cqual to thoso shown by the "Horcules" on the occasion referred to; that is to say, that a "Monarch" firing at another "Monarch," will fail to damage her at 1,000 yards when her shots strilio fair.

But how littlo can we calculate on this result? The general idea concludes that a slip will rarely present her broadside to be fired nt. 'To to fair to both sides, suppose the shot strike nt an anglo of $45^{\circ}$, and the resisting power of the "Monarch" rises from 49 to 98 . In other words, it is doubled. That possible prospect has a "Alonareh" of deciding an action with another "Monarch" by meaus of hor artillery; under circumstances such as these?

But we are only on the borders of the "MIonarch's" powerlessness as jet.

In my paper on Lissa, I cndearoured to show that at tho utmost rapidity possible, the "Belleroplion". could not fire more than 4 rounds per gun in 6 minutes, or 28 rounds in all. I am informed that the "MIonarch" does not calculate on a greater speed of fire in action than 1 round in 3 minutes per gun; that is to saj, the rapidity has fallen from 28 rounds in tho "Bellerophon," to 8 rounds in the "Monarch" in 6 minutes! We hare no grounds for supposing that moro than a trifling increase of accuracy has been gained, and, therefore, I must debit the guns with this further reduction, equal to $3 \cdot 5$ in their power. If my figures approach correctness, the recession of the power of the gun since the battle of Lissa, as exemplified in the "Nonarch" and "Bellerophon," is in the proportion of 1 to $4: 8$. "Tho gurs sro 
now in point of fact, abont five times as weak as they were fire years ago.

This scems to mo a rery startling conclusion to arrivo at, and ono which lies at tho root of all construction and armament. It is not as though it were certain tho gun must meet the gun, and therofore the recession was common to both sides of the equation, but it is that some other weapon or wcapons aro making tromondous stridos, and are beating tho gun in competition. It may mean also that the manner of constructing tho carriage-that is tho ship-is at the bottom of tho recession. In any case, I can conccive no more important subject for inquiry than whether my figures and deductions aro correct. If they are, I can only cxpross my belief that wo aro closo upon a very oxtraordinary re-construction of our Navy.

Thus far, then, for the relatire placo of the gun now, compared with that formerly held by it. Let us look at its actual power in riew of the futuro comparison wo shall havo to mako between it and other wcapons.

Unfortunately, precise figures aro wanting here, and very little attempt has been made to obtain them, as they can alone be obtained by experiment. The inquiry takes the form of two questions: How many shot will strike tho hull of a "Monarch" in a given timo in tho open sea, and wliat amount of domago will they do? and I must own it has struck me as alarningly sugggestive that I cannot get an answer off-hand to cither query. Nobody scems to have mado the calculation, even with sucl data as are obtainable, and no steps havo been taken to improve the data. It is true, I beliere, that the materials for determining the number of shot which will strike a giren vertical target at a given rango, when fired from a stendy platform, aro obtainable, but such a determination must bo a very fallacious gaide to tho results of practice at sea; nor am I sure that eren the materials obtained haro beon applicel to determine the practical question.

MIy tigures must bc, for tlieso reasons, rely imperfect; but $I \mathrm{am}$ obliged to uso what $I$ can get.

Tho 12-pounder rifled gun, at an clevation of $2^{\circ}$, is stated to be capable of placing fourteen shot out of every twenty in a target 9 fect squarc. Speaking roughly, this amounts to saying that two-thirds of the shot fired from a rifled gun are capable of striking a target 9 fect square at a distance of 1,000 jards. Actual practice at Shoeburyness secms to benr out this statement fully; for on firing twenty rounds from the 12-ton gun, tho extreme crror of eleration at 1,000 yards was only 13.5 feet, and tho mean was only 4.7 feet. In direction, the extreme error was 9.75 fect, and the mean error only 4.4 feet. Out of tho wholo twonty shot, four only would haro missed tho "MIonarch;" two would hare fallen short, and two would have gone orer. It appears safe to conclude from these figures that tho "Monarch" is not liable to receire more than four-fifths of the shot fired at her at 1,000 yards; and if tho chances of being hit rary directly as the distance, at 2,000 yards the "Monarch" is only liablo to reccive two-fifths of the shot fircd at her. This is an admission in farour of the guns; for the chances of bẹing hit diminish in a still greater degree; but as tho crror 
given is entirely duc to elevation, and tho "Monarch,". as a target, is very much longer than sho is high, the admission may pass.

Under impossible circumstances, -therefore, if a "Mlonarch" opened firc on anothor "Monarch" at 2,000 yards, she might hit her eight times in ten minutes, bat none of these shot would damage tho si $p$ in a vital part, and probably wonld pass through no part of her plating: I use the expression "impossible circumstances," because to get that result, a steady platform, a fixed object, and perfect coolnes's and deliberation are required, not ono of which conditions can be sewred at sea in action.

I have tried to obtain somo idea of the deductions necessary for tich of these conditions; an unsteady platform, a moving object, and catreno rapidity of firc. But it is not easy.

Taking the experiments carricd out at Vigo between the "Monarch," "Captain," and "Hercules" for what they are worth, it nppears tliat the three ships fired for fire minutes each at a rock distant about 1,000 yards, which was estimated to be 600 feet long and 60 feet high, or twice as long, and four times as high, as a ship. "Hercules" fired serenteon shot, of which ten hit; "Captain" fired eleven shot, and made four hits; "Monarch" fired trrelre shot, and made nine hits. Spcaling roughly, as I am bound to do with rough figures, it would appcar that a ship such as tho "Monarch" would, under those circumstances, hare been lit three times by the "Hercules," onco by tho "Captain," and say three times by the "MIonarch."

We have seen that.:8 of "the shot fired would have hit a "MIonarch" at 1,000 yards, the platform boing steady; wo now find from tho foregoing experiment that . 347 of the "Hercules" shot, .09 of the "Captain's" shot, and -187 of the "Mlonarch's" shot might bo expected materially vary.

The question for us is whether these figures may bo relied on as a gaide-whether they fairly represent practice at sea, or either under or over estimate its accuracy. The only other figures at my disposal in order to check the calculation are the following. In somo recent carefully conducted prize firing by one of the ships in the Channel Squadron, it was estimated that at from 800 to 1,200 yards there were only 25 lost shot out of 208 fired. $\Lambda$ "lost shot". appcars, according to the Admiralty circular, to be one which would miss the "Monarch", passing orer her either en ricochet or directly. The firing on this occasion appears to have been exceptionally good, for a triangular target with 9 feet sides is represented to havo been hit no less than foar times.

If therefore wo are to accept theso shot not counted as "lost shot" to be a fair representation of the percentage of hits in a "Mlonarch" at sca, we shall find it to be 88 of the shots fired. But we have quoted accurate figures showing that at 1,000 yards-a mean of the distances at which the practice under review was carried on-no moro than $\cdot 8$ of tho shot fired will striko a "Mlonarch" when the distance is accurately measured from a fixed and steady platform, and the gun is laid with a nicety impossible afloat. This 88 of hits cannot be therefore a true 
representation of tho practice; and I think naval men generally will admit that observations of the fall of shot taken from the mast-head and extremes of the ship, are, at their reery best, of an extremely rough character. The tendency of obserrers in such circumstances is almost always to exaggerate the accuracy of fire, as I am bound to confess appenrs to be the case in the details of firing under consideration.

But we have seen that the probable number of hits on a target 9 fect square, at about 1,000 yards, is 14 out of 20 . A 9 -fect squaro target gires an aren of 81 squnro feet, while an equilaterul trianglo with 9fect sides gives an area of 35 square fect in round numbers. Accepting the assumption that the fall of shot on a given surface varies as its arca-which I think will be true enough for our present purpose-we should find that 3 of the shot should strike the floating target in tho case referred to. But as 4 only out of 208 struck it, the actual hits were $\cdot 019$ of the shot fired.

Now compare the results of these two investigations. According to the record of "lost shot," this ironclad's practice was really better and closer than that obtained from a steady platform at Shoeburyness; while, zneasured by the percentage of hits on the target, it was very much worse.

Looking again at the Vigo practice, the average hits of the three ships upon a "Monarch," at 1,000 Jards, was 141 of the shot fired, in licu of the 8 of the shot which would have struck had the practice reached its maximum accuracy. If the prizo firing practice had been as good as this, 053 of the shot ought to lave struck the floating target in licu of the 019 of the shot which actually did strike it; in other words, ten hits ought to liare been made instead of four.

Artillerists may very likely smile at the rudeness of these calculations and surmises. No doubt they are very rude, but I am not conscious of the endearour to establish a foregone conclusion of their means, and, denling with them as rudely as they require to be dealt with, they appear to mo to establish tho probability that a very much smaller proportion of hits by shot will be made in action at sea than any of us hare hitherto imagined.

Is it renlly then the case that at the moderate range of 1,000 yards, under the most farourable circumstances, a "Monarch" can only expect to hit a sister resscl from twice to fiftecn times out of evers 100 shot? And if she carries so many as 1,000 rounds of shot, will only from 20 to 150 take effect? This is a question wo shonld not haro Ieft so long unanswered, and it ought to be ascertained with certainty witlout any delay.

I, howerer, cannot stop to ascertain how tho fact may bo; I must make a reasonable assumption on the facts $I$ am possessed of, and I tako a mean position between the result deduced from the Vigo experiments and those taken from prize firing; and I lay it down that 10 por cent. of the "Monarch's" shot will strike a "Mlonarch" in action at 1,000 yards.

We hare scen that the "MFonarch" is, in leer vital parts, impenetrable to shot from the 25-ton gun at 1,000 5ards. when struck fair. Practicall5, I beliove sho will be so seldom struck fair, that no part of her

voL. $x v$. $2 \mathrm{~F}$ 
plating is vulnerable until within 1,000 sards, and in anything approaching the cud-on position I feel bound to extend this invulnerability to within 500 gards of her adversary. However the question may be argued, it is certain that only a portion of the shot striking the "Mionarch" will penetrate, and we cannot sappose this proportion grenter than one-half with any ccrtaint5. The amount of damage dono by the penctration of 5 shot out of 100 fired must bo small in any case.

I have now tried to answer the question as to the proportion of shot which might hit a "Monarch" at a mean range, and the other as to the damage likely to bo done.

Tho next question arises from a combination of the two facts erolred from the argument, and it enquires "How much danage will be effected "upon a "Monareh" by another in a given time, say six minutes?"

And hero I must endearour to correct the assumed speed of fire by the same data taken to arrive at the percentago of lits.

At the rock off Vigo tho speed of the "Hercules," was 17 shot in five minutes from four guns, being 3.4 shot per minate, or 85 shot per gun per minute. The speed of the "Captain's" fire ras 11 shot in five minutes from four guns, being 2.2 shot per minute, or 55 shot per gun per minute. The speed of the "Mlonarch's" fure was 12 shot in firo minutes, or $2 \cdot 4$ shot per sainute, or 6 shot per gan per minute; tho average of the three ships giving 66 shot per minute per gun. Tho average spead of the prize firing I have used was $\cdot 7$ shot per gun per minute. We must take it therefore that this is tho maximum specd attainable under tho most faromrable circumstances. It amounts to one round from cach gum in a minute and forty-two scconds, so that I do not tluink there need be any fear of adopting the one round per gun in tlreo minutes, which is assumed afloat to bo the probable speed of "Monarch's" firc in action, as representing the truth. But for my purposes I would rather assume something abore the arernge, and if I allow one round in two minutes, and 10 per cent. of hits, $I$ do not think I place the gun at the range of 1,000 gards in action at all in arrear of its actual place.

Our summary of the actual gun-porrer of the "Monarch," therefore, amounts to this.

In six minntes from the opening of her firo on the sister ship at 1,000 Jards, sho will have fired 12 shot, of which one will have hit and another may hare glanced, and it remains an even chance whether the single hit will have penetrated the enemy's armour.

With this extremely curious conclusion to our investigation I shall leave it, and proceed to the newer weapon-the Ram.

\section{Rams.}

If we are to consider the question of tho attack by rams with any hope of a good resnlt, we must begin at the beginning. Wo must endcarour to treat the question from a purcly abstract point of view. We must tale two idcal ships of equal speed and turning powers, and 


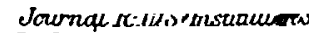

Vol 15

P1.XV1I.

\section{Diagram 1}
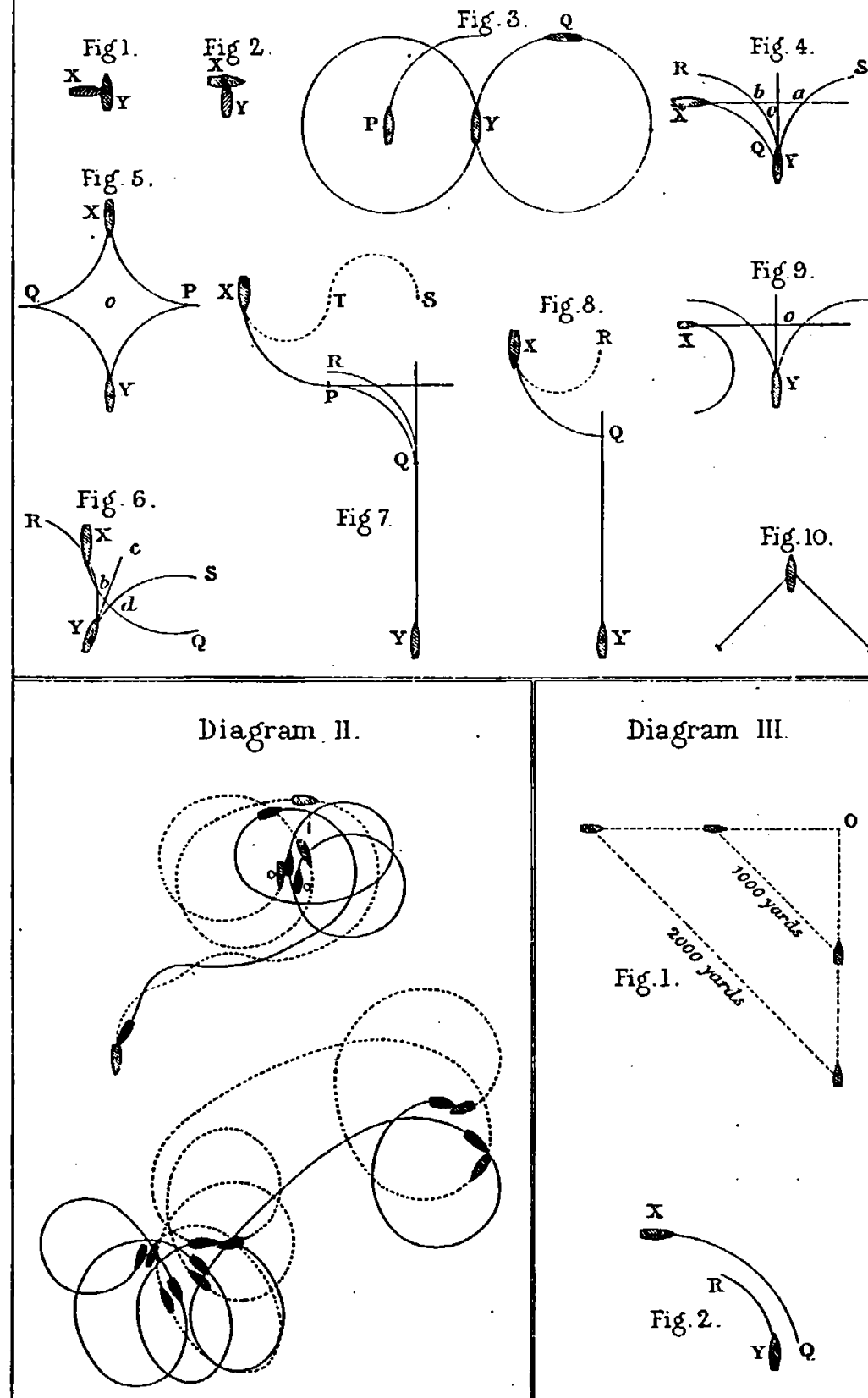

Diagram III.

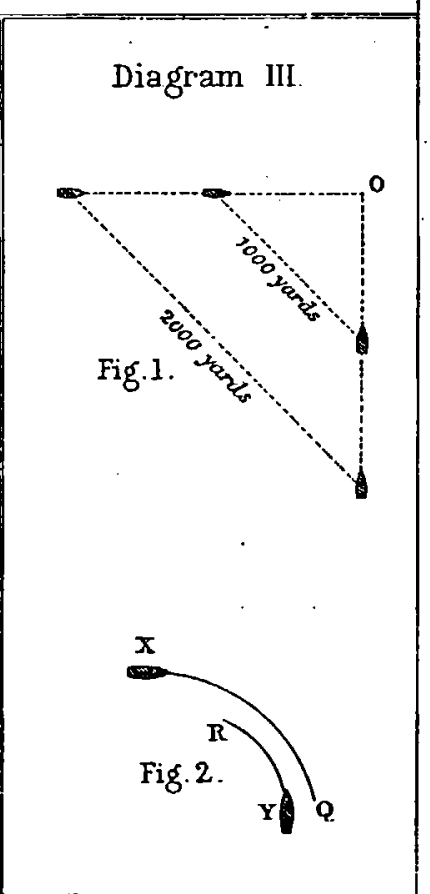

Fig 7 .

Fig.10.

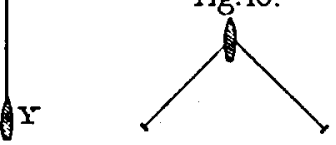

J.Jobbins 
condemn them to abstain from many methods of defending themselres which both would use in actual warfare. No disturbing eauses must enter into our first analysis, but after wo have seen how the easo stands, when both ships are limited to strict rules in thir behaviour, we can ascertain the relativo ralues of those mothods which would be used in practice, and we can determine which of them deserro the foremost place.

While, howrorer, wo select two abstract ships for our purpose, we must tako care they are not impossible types. The relations of the length to the turning powers must bo such as existing types fulfil; and the speed overares must be such as can be realised : and, as it has been ascertained with regard to existing ships, that at their highest speeds they turn in a circle whose diameter is from four to six times their length, we may take a circle whose diameter is five times the length of our slips as a safe picce of data whereon to found our investigation. The two ships in dingram 1, therefore, are supposed to trarel when their helms are hard over, on the are of a circlo whose radius is two and-a-half times their length. We must suppose them for the present unable to reduce their speed, and consequently unable to travel on a curre vith a smaller radius; but we allow them to do anything they wish with their helms; and wo are to suppose each equally anxious to ram his neighbour and to aroid being himself rammed. For conrenience we shall assume the speed of each ship to be 9 knots, and their length to be 100 jards, or 300 feet. The length of each ship in time, that is, the time it will take each ship to pass over her own length with helm amidships, will bo 20 seconds; 10 seconds will, therefore represent half eacli ship's length in time.

It must bo now borne in mind that the fact of putting the helm over reduces the speed over the arc in a degree proportional to tho amount of helm giren. The "Bellerophon," for cximple, when going 12 knots with helm amidships, reduces lier speed to 7.8 knots orer her arc; and when going five knots with helm amidships, she reduces her speed to 3.6 knots orer her arc. This peculiarity in the action of the liclm deserves more consideration than there is now time to give. It is, however, enough for my purposes to state that the fict is so, and that it will affect the question of ramming in the manner to be presently seen. Closer scrutiny of the phenomenon will be found in my former paper on " DIodern Naval Tactics."

If now wo take two ideal ships under these conditions, represented in dingram 1 as $x$ and $y$, we shall observo that so far as $x$ is concerned, her object is to obtain the position given in Fig. 1 as regards $y$, and to aroid that given in Fig. 2. y, on the other hand, wishes the opposite. She desires to obtain the position giren to her in Fig. 2, and to aroid that giren in Fig. 1.

What is the difference in theso two positions? What constitutes the badness of $y$ 's position in Fig. 1, and of $x$ 's position in Fig. 2 ? In both cases these ships are 50 jards too far alead in space; and ten scconds too far ahead in time. What on the other hand constitutes the goodness of 2 's position in Fig. 1, and of $y$ 's position in Fig. 2 ? The ships are in both cases 50 yards behind in space, and 10 seconds 
behind in point of time. It is clear also that if $x$ wero anything between her whole length and half her length in space; and between 20 and 10 seconds in time behind the position giren to her in Fig. 1, she would still strike $y$ a fair ramming blow, for $y$ would not in that time or space be so far ahead as to let $z$ pass astern of her. Again, by as much as $x$ is less than ten seconds in time, or half her length in space, before her position in Fig. 1, by just so much does she run the risk of finding herself in the position given to her in Fig. 2. 2's olject is therefore to bo between 50 and 100 fards behind in point of space, and between 10 and 20 seconds behind in point of time. Her blow will be just as good if delivered abaft her adrersary's benm, as it would be when delirered before it, and if she runs the risk of being too late, she only becomes liable to miss her blow, and does not learo herself open to attack; whereas, if she runs the risk of being too early, she not only misses her blow, but lays herself open to destruction. Even at this carly stage of the enquiry, therefore, it is not "uvimportant to note that if " excess of specd " be capable of substitution for "bcing too carly," and "lack of speed" for "being too late," a ram is not adrantaged by the former in the supposed case.

The ship $x$ in Fig. 1, and the ship $y$ in Fig. 2, . has gained her object and her complete victory. But before she conld have got to that stage, there must liave been a timo when neither had any advantage over the other. They must have once been outside ramming distance, and free from attack, and therefore on an equality. And they may have entered upon the ramming distance on an equality, which had been converted into an inequality by the supcrior skill of $x$ in Fig. 1, and of $y$ in Fig. 2. But they mas have come into ramming distance. on an inequality, and the conqueror may have had it all his own way from the first. Let us, therefore, examine what constitutes ramming distance first, and then what constitutes the inequality.

Every ship when advancing at speed, carries on each side of her two circles of considerable size, within the circumference of which no powel* on carth can place her. These circles will rary according to the specd at which the ship travels, and according to the power sle possesses of stopping herself quickly. Another ship which is anywhere inside this circle, cannot bo rammed so long as she remains there. It is clear from this, that it must be from some point within this circle that a ship will find herself able to deliver a blow safe to herself and damaging to her adversary. Outside this circle neither ship can ever get an adrantage orer the other, both must always be equally free to move. I therefore assume that a ship is within ramming distance of another whenever she is on, or inside, the are on which the other turns. And, extending this definition to meet cases where neither ship is within the circle of the other, though in close proximits, we may say thcir ramming distance is twice the radius of the are described. In diagram 1 , I'ig. 3, I havo represented the ramming distances duc to $y$ under the lypothesis we have assumed, and large as these spaces seem, fou must remember they are only tho averago spaces which existiing slips carry about with them when steaming. The mere fact of being within 
ramming distance of another slip gives no advantage bejond the safety from your opponent's ram. The ship $x$ at $p$, the centro of $y$ 's port circle has no advantage over $y$, because $y$ is also at the centro of $x$ 's circle. Nor has $x$ at $q$ any advantage; $x$ is in precisely the same position as regards $y$, as $y$ is with respect to 2 . But suppose 2 to have como into $y$ 's circlo as in Fig. 4, and we shall sce sho las a great advantage. In this caso 2 is insile $y$ 's circle, and, therefore, safe herself, while $y$ is outside $x$ 's circle, and is therefore open to attack. It seems to me that the whole art and mystery of ramming will be found to consist in this endeavour to get jour adversary outside jour own circlo while you remain inside his.

$x$ has a manifest advantage on the face of matters in this figure. She is excluded from receiving a blow, and is not prevented from giring one. Let us therefore enquire more closely as to the exact chances she las of ramming $y$ under the circumstances postulated.

In the positions giren, $x$ is 40 seconds from the collision point $o$, while $y$ is only 25 . If therefore both ships pursue their present courses, $x$ will ram $y 75$ feet from her stern; $y$ cannot therefore continue her course with safety. Let us suppose she puts her helm hard-a-port, to turn from $x$ along the curre $y s$. The arerage time of turning of four ships of the Cliannel squadron at 12 knots is given as 6 minutes 2 seconds, and at 5 knots, as 10 minutes 4.5 seconds. We may thereforo nssume that our ilcal ship $y$ will complete her circle in 8 minutes; it will consequently take lier 1 minute to turn through four points, which will bring her to $a$. But $z$ is just 55 seconds from the point $a$; and she will, if she goes straight on, be herself rammed by $y, 75$ feet before her starboard beam. She avoids this mishap by porting her own helm, which has the double effect of delaying her progress, and enabling her to strike $y$ a fair ramming blow before she reaches the point $a ; y$ in short cannot escape either under steady or port belm.

If $y$ puts her helm hard-a-starboard, she lias a better chance, for $x$ is ouly 25 seconds from the point $p$, while $y$ is a minute from it, and consequently $y$ may get inside $x$ 's circle and bo safe, before $x$ is aware of it. But $x$ can only lose his chance from want of shill. It is his sole business to keep inside $y$ 's circle, whatever happens, and ho should put his helm liard-a-port inmediately, and turn along the arc $x q$. If $y$ now persists in keeping his helm over, $x$ has only to reverso his own at the right moment, and give $y$ a fair ramming blow amidships.

In the case before us, therefore, y does not appear to be able to aroid the stroke of $x$ 's ram by anj emplojment of her helm. If 9 knots is lier utmost speed, she cannot now. increase it, so escape by that means is cut off. If she had it in her power to reduce her speed instantanconsly to $5.6 \mathrm{knots}$, she would only reach the point $o$ at the samo time, and therefore on an equality with $a$. It may be assumed that a ship of any size could not reduce her speed by so much in so short a time; but let me remark, parenthetically, of the difficulty $I$ am placed in for want of data on this subject. It will be clear to you all, that next to a knowledge of the turning powers of ships, and the theory which may be found to lie at the bottom of it, there is no moro important considerntion for any one proposing to attack by zams, than the timo and space 
within which tho ram can stop herself, or relnce her specl to a giren figure. Yet I am not aware that tloe experiment has been tried with nny ship, or that it has been so much as noticed as a requirement.

Howerer the actual case may bc, we maj reasonably assumo that $y$ cannot reduce her speed so as to be 20 scconds later than $x$ ju arriving at the point $o$. But she may hopo to escape by reducing her specd, and putting her helm hard-a-port. Let us suppose that she can and does reduce her speed instantaneously to 5 knots. What is the result?

The difference in the diameters of the circles of four ships of tho Channel squadron at 12 knots and at 5 knots, was only 53 jards. Tho radius of $y$ 's arc at $E$ hnots cannot therefore be assumed to differ from that at 9 knots, by more than a quarter of a ship's length. Hence the arc $y$ now describes will not cross $x$ 's path more than 10 or 12 yards to the right of the point $a$. This is not enough to save her, in fact it brings $x$ 's blow still nearer the midship point. But besides making this trifling alteration in the matter of space, $y$ 's reduction of speed has made a more considerable one in tho matter of time; $y$ will take 20 seconds longer to cross $x$ 's patl under port helm at the reduced speed than she did under the full speed of 9 knots. Wo deduce this fact from the knowledge wo have that the average time of four ships of Channel squadron in completing their circles at 5 knots, was 10 minutes 45 seconds, in lieu of the 8 minutes calculated as the time of turning at 9 knots.

Supposing $x$, thereforc, to allow herself to fall into tho trap, and to proceed along the line $x$ a at speed, she would cross $y$ 's path entirels, just before the latter renched the point $a$. But before she got so far as this, she would hare surrendered her advantage over $y$, in having got outside her circle, and allowed $y$ to get inside hers. Admitting she was unshilful enough to do this, $y$ can only deliver a 5 -knot blow upon $x$, and has surrendered so much of her power by reducing her speed to that figure. But we cannot supposo $x$ would lightly surrender her advantage when sho can keep it by the use of a little port helm. In this case it is evident that $y$ 's delay along the curre $y$ a, leaves it open to $a$ to gire her a perfectly fair ramming blow almost at lier leisurc.

There is still one last course open to $y$, mamely, to reduce speed with the helm hard-a-starboard; and this scems to me the most judicious thing she can do. She will now take 1 minute and 20 seconds to reach $a$ point ahead of $x$, somewhat nearer to her than tho point $b$, which latter is, by our hijpothesis, 25 scconds only from $x$. If $a$ thereforo delays an instant in putting her helm hard-a-port, her circlo will pass ahead of $y$, and she may find herself open to the blow of $y$ 's ram at the reduced speed, or, if she saves herself from the danger, there may not be room for luer to giro $y$ a stem blow. The two slips will, in short, most probably rub brondsido to broadsido in passing, without material damage to either.

But it must not be supposed because $y$ does the best thing possible under the circumstances that she gains any advantage orer $x$; she may recorer the position of equality she originally lost, if $v$ is unslilful enough to permit it, but that is all which is left open to her, and in any caso her 
reduction of spect is a surrender of her mancearzing power directly in farour of $x$ 's proceclings. It is open to $x$ to rednce lier speed at the same timo $y$ reduces hers, in which case she retains all her former advantages, except that her blow, if delivered, will not be so heavy.

I hare not time on the present occasion to pursue the enquiry as to whether the position I lave assirned to my two ships in Fig. 4, is really the worst for $y$ and tho best for $x$; it is safficient for my purpose to show that it is a position extremely desirable for $\imath$ to seck and for $y$ to aroid, and that if $y$ unhippily allows herself to get into it her fate is verg nearly scaled. I think, howerer, the general principle may be assumed that the grand object of an attack and defence by rams must bo to keep jonr adversary outside your circle, and at the same time to keep within his.

Tho next point we havo to consider is how should 2 approach $y$ so as to get into the desirable position?

'There is a rery prevalent idea afloat that the cnd-on position is tho one proper to bo assumed. It was one held by mjself also, I may say, until I undertook the preparation of this paper, and I can, therefore, the moro freely denl with it, aud, if necessars, condemn it.

Let us suppose, then, that 2 and $y$, meeting in the open sea, and being cach imbued with tho necessity of kecping the end-on position, steer for each other. They must cither give up their cnd-on theory, or they will at length reach tho position giren in Fig. 5 . They aro now within ramming distance, on an cquality certainly, but cach precluded from using thic weapon that each is eadeavouring to use, unless they aro willing to try which is tho hardest at the point $o$, an extremely im. probable conjecturc. But obserre the position they have placed them. selves in. They must either stop where they are, and gire up all hopes of ramming, or they must dash at cach other on an equality, or ono of them must try some other plan. What plan is open to her, let us say, to $y$ ? She may turn along the curre $y p$, or along the carro $y q$, or aloug any curre between those.

Let us suppose sho puts lier helm hard-a-port; in 30 seconds the ships will be in the position given at Fig. 6 . In this position $y$ has tarned through two points, and is just abont surrendering ler equality, and allowing $x$ to come within her circle, while she herself is outside a's circle. The danger of her manourre is not so great as it at first appears, but there is no doubt that sho has surrendered all hopes of using her ram upon $x$.

That sho is not actually in danger may bo noted from considering that she is 30 seconds from the point $d$, whilo $a$ is ono minute from it; $y$, therefore, has a good chanco of dragging her whole length across $x$ 's aro beforo she reaches tho point $a$. But $y$ has a still better chance of escape if sho now rights her helm, for sho is only 20 scconds from the point $Z$, whilo $x$ is 53 seconds from it. But; whatever her clanees of escapo may be, sho has no chance of attack, and, as it may bo assumed that any uovement either ship might make from the position giren in Fig. 5, would result in a position similar to that in Fig. 6 , wo must take it that there is a fundamental crror in the end-on approach of two slips intending to ram. 
It may bo true that the end-on position is proper io aroid being rammed when there is no intention of ramming, but this is not the ense we are now called on to investigate, and is assuredly not the case supposed by thoso who hare abrogated the flank method of cvolution in favour of the oblique.

Let it be noted lece that though from a consideration of Figs. 5 and 6 , there is grent objection to the end-on position when urithin ramming distance; there is noobjection to it bejond ramming distance; but then, on the other hand, neither is there any objection to the broadside position, or, in short, to any other position. The question of the nature of an crolution does not seem, therefore, to be affected at all by the proposal to attack by rams, although the nature of a formation may be. The only morement undertaken when within ramming distance would be the final sweep to ram, or aroid being rammed. Any preparation for this final sweep must bo made bejond ramming distance, where the ships are free to use what nleans they please.

As this end-on approach is not to be sought for in a ramming attack, because of its liability to result in a position given at Fig. 5 , the question is how should two ships approach each other who are equally ready for the combat?

The answer is to bo found by considering that the only difference between $x$ and $y$ in Fig. 4, is that $x$ is half a ship's length further from the collision point $o$ than $y$ is. Wo must expect the struggle to bo to keep the courses at right angles to each other, but to be rather behind in reaching the point whero they cross. The tivo ships may, therefore, steer for each other in the first instance, but before they close they will each mutually assist to place their courses at right angles, and to keep them so, or one of them by superior skill will approach on something near the end-on position until he can by a sudden and unexpected movement bring himself within ramming distance, at right angles to the other's course, and inside his circle at the same time.

In the first case, each ship would immediately bring the other, four points on the bow, and so gradually approach each other, and the most skilful of the two would by such means as were open to him take care to be a little behind at the last moment, ultimately taking the place of $x$ in Fig. 4.

In the other case the ships would stecr directly for each other at first, and might be expected to assume parallel courses, at such distanco as would be determined by the most skilful of the two, and. wo should thus ultimately find them in a position similar to that given in Fig. 7. Here $x$ las determined to get into the position $p$, by a turn of eight points to port, at the same time as $y$, by pursuing his course, arrives at the point $q . \quad \alpha$ is 2 minutes from the point $p$, consequently his turn must bo made when $y$ is 2 minutes, or 600 yards, from $q$. Tho distance between the paths of $x$ and $y$ must be equal to the diameter of the circles, or else $x$ cannot come into position at $p$. 2 will consequently commence proceedings when $y$ is at the great distance of 1,200 yards from him, and nearly $2 \frac{1}{2}$ points on her bow.

If all goes well, and $y$ permits herself to fall into tho trap, $x$ will certainly gain her wishes and destroy or damage $y$, being herself in 
perfect safet.5; and thero is certainly this to be said for such a method of attack, namely, that $y$ will only obserre the bearing of $x$ to alter a couple of points, will have little guido as to her intentions, and only two minutes in which to make up her mind. Tet, of course, any morement of $y$ 's helm either way, beforo sho reaches tho point $q$, will overthrow $x$ 's calculations, and make it necessary to try somo other plan. $y$, however, may divine $x$ 's idea, and may, by slight alterations of course to port, bring herself within $x$ 's circle when she gets abreast of the point $q$. She will thus turn the tables upon $x$, which is just tho risk she runs, and which may arise from a miscalculation of tho distance or speed of $y$. The point to notice is, that this method of approach on parallel courses, a diameter apart, is one which may bo adopted by two ships equally anxious to try their skill against ench other in ramming.

We should notice that $x$, in adopting the foregroing method of approach, proposes to obtain her object by a doublo movement: ono into the safety position inside $y$ 's circle, and the other the delivery from thence of her final blow, and she leaves it in her power to abandon her intention at any moment prior to reaching tho point $p$. Having once reached it, she places herself in the power of $y$ if she turns out to be a certain distance to the left of $q$.

But $x$ may also decido to deliver her attack from the outside of $y$ 's circle, and only to come within it at the moment of collision. In this case, she will approach on a course parallel to that of $y$, but only one radius distant from it, as shown in Fig. 8 . Here $x$ must put her helm orer when $y$ is $1 \frac{1}{4}$ points on the bow, and about 850 yards off, and she will arrire at the point $q$ a littlo after $y$ reaches it, supposing the latter to steer a straight course. But it is most unlikely that $y$ will put herself into the wished-for position. The change of helm by $x$, will be very apparent to $y$, and her design almost equally so, and the smallest possible morement of helm may not only baulk it, but placo $x$ in a very difficult position, for it is possible that $y$ might meet $x$ within ramming distance, while the latter had her helm hard orer, and the former had her's amidships. In this case, $x$ would clearly havo only half the mancouving power of $y$, and might suffer for it. $x$ in short cannot make a re-calculation of her position and prospects when within ramming distance, should sho attack in the method given in Fig. 8, while sho can well do so should she attack as in Fig. 7, and should sho choose the first method of approach, bringing her enemy rather less than four points on her bow, and forcing hęr to keep so, she is perpetually re-calculating her chances and position.

Wo hare now discussed roughly tho principles of an attack by rams from ahead, when the ships have equal speed and turning powers, and $I$ think it is apparent that the 4-point method of approach is the one we should choose under the circumstances.

We may now look into the adragtage, if any, which $x$ would gain from the possession of superior speed. We may in cloing so, leare out of tho question those adrantages which speed gives in bringing the enemy to action against his will, for we aro supposing both ships equally anxious to meet. Wo need not, therefore, troublo ourselres 
except with the changes which greater speed for $x$ mould introduco in leer position in Figs. 4, 7, and 8. In Fig. 4, if $a$ liat a speed of 12 knots in lien of 9 , she would, by pursuing a straiglit course, striko $y$ nearly amidships at the point $o$, instead of well abaft her beam, she might therefore begin her attack from a position fartler astern, and therefore safer from a miscalculation of tho sizo of' $y$ 's circle. This would be hei advantage also in criso $y$ put his helm n-port. But on the other hand, if she found herself at the position giren, with this extra speed upon her, sho may be obliged to forcgo her attempted attack in order to saro herself, for if $y$ puts his helm hard-a-starboard, $x$ is adrancing so rapidly that sho can hardly avoid allowing $y$ to get inside her circle, and the moment that happens, sho is either at $y$ 's mercy, or sho must escape ander starbonrd helm and her superior speed.

In Figs. 7 and 8, the adrantage of superior speed is that $x$ may allow $y$ to approach more closely, and thereforo under a better estimato of her distanco before she turns : there is no other advantago linown to me.

Reverting then to Fig. 4 , if $v$ with greater speed than $y$ means to attack her with the same advantages as $x$ is now seen to possess in the diagram, she must cither bo further from the point o herself, or $y$ must be nearer to it; bat the skill required at the low speed and at tho ligh speed is cqual, and the dangers of being rammed instead of ramming, are possibly a littlo increased. I do not look apon great speed consequently as very important for a ram.

But if the question is not one of permanent speed, but of the power of increasing or reducing the specd of the slips rapidly, then there can be no question of tho advantage. The increased speed will sare the ship from being herself rammed, and the power of reducing it will enable her to ram effectively, and hence we may assume that a very heary ship is an inefficient ram, for slo cannot have the same powers of rarying her specd as a much lighter one would have.

But now, suppose $a$ with no advantage in speed, is half tho length of $y$ with the samo proportionate turning powers, and obserro the conditions under which she will meet $y$ in lig. 9 . It may be seen at a glance that she has $y$ absolutely in her power, for she has all the advantages sho beforo possessed, besides tho infinite adrantage of manceuvring freely within $y$ 's circle, and being able to frustrate in the most perfect manner, any attempt of $y$ 's to cscapo under starboard helm, which wo beforo saw was really her only chance.

Then again, look at Figs. 7 and 8 as to her facilities for attack under the new conditions. In Fig. 7 , if $x$ had miscalculated her distance and found $y$ would bo too far ahead to bo rammed from tho point $p$, her stroko was altogether lost, but under tho new conditions sho may commence on the curve $a 1$, bit end on the curve $t$, thereby having it in her power to move tho point $p$ to suit tho morements of $y$. Whilo under the old conditions, tho boundary of hor possible movement under starboard and port helm was $\imath p q$, it is now enlarged to $x t s$. So in Fig. $8, x$ may commence on the curre $x q$, but has a reserve of manoouvring nower as far as a $r$. 
If it bo said that $y$ by increased speed can make up for a's increased turning powers, I think we must deny it, unless $y$ surrenders all idea of ramming, or cren of allowing her adrersary to come within ramming distance. If sho allows $x$ to close her, and to get into the position given at Fig. 9-which sho is very likely to do-lier speed will hardly save her; for allow her 12 knots to $x$ 's 9 in Fig. 9, and she cannot escape under starboard helm, she las not a foot to spare under port Inclm, and sho has not $n$ ship's length to spare under steady helm; and it is not to be supposed that $x$ in the confidence of her manourring power, will not provide against this chance, by kecping much closer to tho point $o$.

There is, howerer, a method of attack for which superior speed is necessary to success, and that is the attack from tho rear, cither directly or by an adranco past the adrersary, and a turn upon her. of the dircet attack I need not speak much; it would doubtless be possiblo for a ship with superior speed to chaso and to ram a ship of inferior speed, which declined to tace her. Bat tho blow so given would be a light one, as its relocity would only be the differenco between the two speeds, and it would undoubtedly be long in coming. The indirect attack is made by the ship with superior speed coming up from tho rear on a course parallel to her adrersary's, aud one radius distant, then drawing sufficiently alhead to strike her at right angles by a turn of 8 points. This case is ably treated by Admiral Boutaliov, and I agree with the conclusion he draws, that the adversary need never allow herself to be so rammed; she can see the opponent gaining on her, and must know what tho result will be; she can then either turn from her or towards her in perfect safety, and the result. will ultimately be the direct attack $I$ have noticed.

Long as we hare dwelt upon this question of tho ram as a weapon, it must be apparent to all that I liavo only touched the outshirts of tho question, and until Naval Officers will turn their intelligenco fully upon it, on the outskirts of the question wo shall remain.

We hare, however, I think, shown a probability that the following conclusions approach the truth:-

1. Tho end-on position must nerer bo taken up by a ram until the moment her spur strikes the object.

2. Extreme speed is not so necessary for a ram as extreno porrers of turning.

3. Great lengtlı and woight aro an inconsenience to a ram. It may bo added that thes aro not necessary for an effective blow. The work done upon a ship by the $400 \mathrm{lb}$. shot from the 18-ton gan is under 5,000 foot tons. Tho work done by the stem of a ressel weighing 1,000 tons, propelled at 10 hnots, is cqual on impact to 4,270 foot tons, and the work is done below the armour.

4. So far from ramming being a diflicult or impossible task, it is a thing which can be accomplished by superior skill with ressels otherwiso equal. But a ram whose turning powers are much greater than her adrersary's, may attack her with every confidenco of success.

This seems the placo to advert to tho ordnance proper to bo carried by a ram. 
I must confess myself doubtful about tho end-on fire-a result I did not at all expect to arrive at when I planned the paper. I had in my previous papers laid it down that $I$ would in no caso uso my guns on approaching to ram, but that I should be glad to sce my adrersary uso his, because my movements would be disguised thereby, and I observe a grent French authority, Admiral Jurien do In. Gravière, has recently advocated the same view. If this is so, when is a ram to uso her artillery? The answer seems to be, when she has missed her blow, and is passing her adversary broadside to broadside. Except at that moment, "Tho poor advantagc," as Admiral de la Gravière sass, " to " be gained by a discharge rendered uncertain by the rapidity with " which the distance raries, cannot compensate for the cloud of smoke " which would envelopo tho ship at the all-important moment, when " her safety depends on the precision with which she is handled."

It may be argued that this is true enough of the caso when within ramming distance, but that ships should be armed for end-on fire beforo coming within it. The answer to this is, that we hare seen how a ship may really commence her ramming manocurre at the distance of 1,200 yards if sho approaches the end-on position, and that if she approaches on a 4-point bearing, a very slight alteration of course, will bring her broadside guns to her.

I thus conclude the rough cxamiration of tho ram question as applied to single ships, and as separated from artillery fire and the torpedo. I must now pass to the latter and newer weapon.

\section{Torpeloes.}

In the very admirable paper giren to us by Captain Dawson, on Offensiro Torpedo IVarfare, he expressed his conviction that we were neglecting a rery powerful and valuable weapon in the outrigger. torpedo, which lie belicved applicable to flects. Unfortunately experiments on the question are wanting, and it wonld not be possible, in the absence of them, to make the outrigger torpedo a basis of attack and defence. This much may bo said for them, however, that if they succed at all, they will certninly succeed in an attack from the rear. I hare shown that a vessel with superior speed may strike another about the stern with an incflicient blow, equal to the difference between their speeds. Theso are the conditions under which the outrigger torpedo would supply tho deficiency. The vessel using it, consequently wants speed, but need not be a ram. Captain Dawson thinks they might be employed in outriggers at right angles to the kecl, and be so used by a ram which had missed her blow and was passing broadside to broadside of her object. Under such circumstances tho torpelo would compete with the broadside gun, and I am rather inclined to think the latter to be the more effective weapon.

The Harrey torpedo secms to me a weapon by itself, and not an auxiliary, like the outrigger torpedo. I understand that Captain Harrey deprecentes its uso in ordinary ships, and proposes special ships, to employ no other weapons. To ne, howerer, it seems a weapon well adapted as a defenco against rams in large and long ships. If tho ship 
$y$ in Fig. 9 was known to bo towing a torpedo on her port quarter, as in Fig. 10, it enormously increases the hazard of $x$ 's attack, although it need not deter her altogether. Her tactics would be, in the erent of missing her blow, to pass close under the stern of $y$, trusting to run over the torpedo line. The danger, however, would be great, for the line might casily bo fouled, and then $y$ 's progress might draw it under $x$ 's bottom and explode it there.

The Harvey torpedo ressel does not require anything but great spced, but this sho must hare to be efficient. The tactics she pursues are very much simpler than those of the ram, for she does not want to bo in a particular place at a particular time; all she requires is to pass her adrersary within about 200 yards on any course, and her mission is fulfilled if she succeeds in doing so. In the attack by such a ressel on another of her class, shill appears useless as nigninst speed, and it would scem the slowest ship must be destroyed. The object would probably be an endearour to cross each other's bows, and the fastest ships must ultimately do this.

'These few remarks are all which seem to me necessary on the question of torpedoes as applied to the attack and defence of single ships. They aro weapons destined to plas an enormous part in tho operations of future naral war, and if hereafter I continue this subject, their immediate part in fleets must be cxamined, but as regards the chief of them, the Harrey torpedo, I don't sce how it can be discussed by itself. A Harrey torpedo ship mecting another, in the open sea, and knowing her to be onc, cannot run down upon her and trust to chance as to which torpedo takes effect first. She may certainly approach as a ram $(x)$ would in Figs. 7 and 8 , with the intention oi crossing $y$ 's bows at some distance; jet $y$ can never be supposed foolish enough to run such a risk. If she thinks sho has snperior speed, she will earefully abstain from all close quarters except with her licad the same way as her enemy, and with helm amidsbips. It is not as in ramming, where a distance of 50 yards or so makes all the difference between victory and defeat. It is more a question of superior speed, and a knowledge that the superior speed, properly used, must destroy the adversary by torpedo, just as superior turning powers must destroy her by ramming.

The effort of two torpedo ships, it seems to me, will be confined to ascertaining which has superior specd, and tho strong probability is that in the ascertainment of that fact one of the two will perish.

\section{The Attacli and Defence of Single Ships.}

Only now, after this separate treatment of the gun, the ram, and the torpedo, are we in a condition to combine them, and to obserre the effect under such circumstances. But before procecding to such combination, it appears to be the proper moment to adrert to foreign naral opinion on the status of the reapons. I must leare the torpedo out of this account, for I know not tho opinion entertained about it abroakl.

The rise of the ran in foreign estimation is one of the most re- 
markable features of the age. Dating from the first utterances of our gallant Admiral of the Flect, Sir George Sartorius, the ram has carricd all navies by storm, and, so far as I cnn gather, cxcept in Russia, without enquiry. When I read my paper on MIodern Naral Tactics here, in tho year 1865, and acknowledged myself a complete convert to Sir Gcorge Sartorius's views, English naral opinion was incredulons. Admiral Boutakov had written ably on uaral tactics, but had nowhero cxpressed a conviction that the ram governed the tactics of the future, although an enquirer so acute and unprejudiced could not avoid allusion to its growing importance. In France, a sjstem of tactics based wholly on the supposed nnrivalled empire of the gun existed, and there was only the faintest glimmer of an idea that the old line of battlo was about to fall from its liigh estate.

Now look at the clange. Admiral Boutakov has worked at the ram question to an extent unattempted by us; and Russia has drawn up lier scheme of naval evolutions on the arorred principle that the ram is the ouly weapou of value against a flect. France has pushed her old system of erolutions into the back ground, in the firm belief that the ram, and the ram only, need be feared at sea.

The ramming experiments triel by the Russians under Admiral Boutakov, are altogether too interesting to be left without a passing notice. He took two gunboats of 200 tons each, and fitted them up as harmless rams. A sort of gabion or extra largo fascine was fitted to the stems of theso craft, and a bolt of fascine work ran all round their gunwales. Captains of two of the ships present were placed in respectivo command of the rams; they wero turned brondside to broadside, head and stern, and started to daminge each other as much as they could. Cross-bearings of the tro rams were constantly taken during the continuance of the struggle, and the corresponding tracks inapped out. Two of these encounters have been reproduced in diagran II, where the dotted line represents the track of the ram "Priliv," commanded first by Captain Kolong, and secondly by Captain Vogak. It was a rule in these encounters that a Captain lost his command when he was rammed, and consequently somo Captains of greater skill slew sereral foes before they lost their own command. The strugglo represented in the npper figure lasted 16 minutes, and tho track of the victorious ram, the "Goul," commanded by Captain Ivanor, is shown in black. Iranor was again victorious in the struggle shown below, but not till 30 minutes had elapsed. Twenty-one of these encounters are given in the pages of the "Rerue Mraritime," and tho shortest timo in which the ramming was effected was 5 minutes; the longest being 50 minutes; the arerage being just 20 minutes.

No doubt the battle of Lissa has had much to say to the adrance of the ram question, but in England wo did not lay that lesson to heart as Russia and France have done. The confirmation of my belief in tho ram which Lissa gave, and which I very strongly put forward, carried onl 5 a small section of the service with me. I was still met as before, by the remark that it was rery difficult to ram anotiner ship, and $\mathbf{I}$ beliero that eren now only a section of tho English $\mathrm{Navy}$ is disposed to forsake the trust in our guns and to pnt it in our stems. 
: I am not completely in error on the question, I hope that what I aro already said to-night will lead my brother Officers to look into tho uatter more closcly than they have jet done, and with minds so much core capable than mine, to ascertain what the truth may be, and not to st satisfied with mere vagno phrases and vaguer thoughts.

Let me now briefly cndeavour to picturo what the nature of a dnel t the open sea would be between two "MIonarchs," cach equally ready is the fray, but one of them determining to use her guns and dependig upon them, and the other looking at her guns as a secoudary enpon. To kecp up our terminology, I shall call a the muming ship id $y$ the ono depending on her guns. $x$ would, on first sighting her" lversary, bring her about 4 points on the bow and manœurre so as to zep her there, while she advanced at speed. y might bo expected to cer direct for her enems, trying perhaps an occasional long shot al swerving slightly to do it. At about 2,000 fards distance, would find it convenient, if not forced to do it before, to bring aboat 4 points on her bow so as to keep a steady fire upon her, hich we must suppose from that moment to commence. They are tch now, in Fig. I, diagram III, 1,400 yarks from the point at which teir courses cross; and if they were going $10 \mathrm{knots}$, - whicli $x$ at least ill be certainly doing, as sle knows her greatest safety from shot lies the rapid alteration of eleration of $y$ 's guns, -if they were each going ) knots, they are only 4 minutes 12 seconds from collision. What image can $y$ do with his shot in that time? She may fire two shots om cacl gun, or eight in all, of which we have seen none would hit the ship was steady at 1,000 yards; and the distances at which cse shot are fired raries from 2,000 yards to nothing. The ganntlet bich $x$ runs is a bagatelle, no ship need fear it, and if $y$ has laid herIf open, and permits $x$ to get into ramming distance, as in Fig. 4, agram $I$, it is all over with lier, unless she has reserved her fire for tho preme moment. But we may be quite certain that no fire will be serred. She will have exhansted all her efforts in combined accuracy id rapidity, and $x$ will only run the chance at closo quarters of recciri a stray shot badly aimed, as it is sure to bo at such a time. If $x$ is passed througle \& shots, a minute before collision, sho is safe from 5 further firc.

But suppose that $y$ is wise enongh to perecivo his danger, and to ru towards $x$, along tho curre $y r$, Fig. 2 ; $x$ cannot now ram conniently, he therefore takes the step ho had previously prepared for, d brings his guns into play. His method is to sweep round upov e large circle $x q$, with his guns trained right abeam on the starboard le. In 30 scconds he discharges them full into the plates of $y$ at tol range, and passes away nuharmed to prepare a renowed en. anter.

I cannot pass a rery probable feature of this hind in a naval duel, thont remarking on tho adrantage $y$ would liave were she armed as roadside ship). If $y$ discharges her port broadside at $x$, two minates 2st clapse before she does it again; more than two minutes must pso beforo sho can transfer her fire to the opposito vroadside; conjuently $x$ has it all her own way in passing starboard side to star- 
board side. If $y$, however, had a second set of guns ready on her starboard side, $x$ might take less from her mancuvre.

Time does not permit mo to dwell longer on a part of my subject which will bear any amount of the closest study. I haro inclicated what seemed to me tho absolute ralues of the gan and the ram, and I have endearoured, $b_{5}$ bringing them into opposition in a fight between two ships, which I imagine to be a representativo combat of its kind, to get at their relative values. I might infinitely rary the circumstances of approach and subsequent conduct, but so long as $x$ acts on the assumed superionity of his ram, and $y$ on the assumed superiority of his guns, their combat must partake of the natture of that I have sketched out. $x$ will agnin and again make his effort to ram, and will only take to his guns after ench failure; $y$ will persist in believing he is damaging his opponent, which in my view ho will not do, and $x$ 's failures to ram will not prerent him damaging his opponent effectually by his broadside gans.

There are some points to be noticed in the details of such a combat, as I have sketched. $x$ cannot be put to a disadvantage bs the direction of the wind, wherens, if $y$ is unliappy cnougl to cngage to windward, the smoke from lis orn guns will hide $x$ from him, and will, while it interferes with his own fire, effectually shicld the operations of $a$ from view. $y$, howerer, is not at all hidden from $x$, who observes her every movement at his leisure.

The temptation to go at slow speed so as to make better shooting, is rers great; jet nothing could be more dangerous than to be canglit at slow speed within ramming clistance by a ram.

It may be thonght that it is improbable that all combats should take the form I liave sketched ont, but $I$ think it is possible, that if qne ship determines to leep her opponent on a 1-point bearing, she compels her to do the same, as being the only way of approaching, so that. the ram is still the master, ereu in directing the method of his enemy's approach.

Wherever the Harrey torpedo makes its appearance, whether in company with guns and rams, or by itself, it is still specd which must carry the day. Whaterer one slip may think of his guns or his ram, ho must try his speed and his torpedo, if the other chooses to adopt that mode of attack. $y$ could not, as in Fig. 2, diagram III, if $x$ was towing a torpedo, turn towards him and allow him to cross his bows: lio must turn amay from him, and trust to his own torpedo to keep $x$ 's ram clcar of him. Hence they come to parallel courses, and artillery fire, brondside to broadside. The struggle will immediately be, which is to hend the other, and whicherer can succed, must be rictorious. The tendency of the Farrey torpedo scems thus to $b c$, to bring the gun forward again, as tho tendency of the ram has been to push it back. While this struggle for precedence continues between two torpedo vessels at short range, much damage must be dono by artillery; and if the speed of the ships is nearly equal, the combat might be decided by a broadside action of the old type, except, that it is carried on at ligh speed.

Hero then, I close, my cxantination of the bases on which the attack, 
and defence of modern flects must rest, and no one can be more conscious than I of its vagueness and imperfection; but I hopo it will be admitted, that I could not procced to carry out the examination set forth in $\mathrm{my}$ title, until I had come to somo conclusions, such as I hare put forrard: and, in any case, I trust to have shown, that with proper experiments and deductions therefrom, the relative importance of tho reapons wo are dealing with, and their judicious cmployment, first, in singlo ships, aud finally, in flects, may be fairly cstimated.

I must not quit the subject without adverting to those principles of zonstruction and armament, which the matters wo hare been discussing, ippear to recommend.

End-on fire appears less a desideratum than I at first supposed it would turn out. For a ram it seems quite unnecessary, as the lattor iecuis to combino mach more satisfactorily with the old-fashioned broadside gun.

The ram, puro and simple, is strongly advocated as a weapon, by Sir Teorgo Sartorius; and I must own that, it secms to me, a gunless $\mathrm{rmm}$ if equal speed with tho "MLonneh," but about one-fifth her size, would neet her on equal terms in the open sea.

If such a ram were to attack, a larger ship could best defend herself yy a large number of light shell guns. Such might bo easily employed $\mathrm{n}$ a broadsido ship, in addition to her plate-piercing armament, but sould not be employed in the "Monarch." If, howerer, it is found hat a ram of 1,000 tons can be so plated as to resist all but the reaviest shot when strikng at an angle of $45^{\circ}$, then it appears to me, here is no lielp for the larger and more unirieldy mass such as the "Monarch," except the toring torpedo.

If light swift torpedo ressels aro designed, a heavier and slower ship nust meet their attacks by multiplying the numbers of lighter guns arried.

On the whole, it does appear to me a matter for very serious consideraion, whether this struggle after guns which will pierce the heariest lates at long range, has not overshot itself-whether the point has ot already been passed at which the reduction in the number of shot, hich can be fired per minate, is compensated by the increased power f the gun.

But while it is impossible to dogmatise on these various points, am mrong in thinking that the service and the countrs, should seriously ndertake to determine the relative values of the gan, the ram, and the rpedo, and not to rest content for one moment longer in an atmosphere f misty ideas on tho question?

The Cuarrusus: If any gentleman has any question to ask, or any remarl to ake, I am sure Captain Colomb will be glad to reply to him.

- Captain DAwsox, R.N.: When Captain Colomb read a rery interesting paper, ur Jears ago, on a similar subject, I went nwaj very painfully struck mith lo fact, that there were so few experienced Officers present who attempted to apple with the subject brought before them, and to gire us the benefit of their. :perience. I hope that we shall not hare the same complaint to make this ening. I did not quite agree in all respects with what fell the other erening i the subject of "naral education" from a brotber Offecr, that Naral Oficers VOL. XY. $2 \mathrm{G}$ 
are altogether deficient in tho logical or rensoning faculty. If that idea be still held b5 my firend, I think tlat to-night he must hare been disabused of it rers much indecd, for Captaiu Colomb has shown that he has not lost his reasoning powers during his recent serrice afloat. Confining mysclf to tho general subject, I will not enter into the details of this paper, which we cannot do off-hand. Tiliere has been no real fighting in carnest at sea since the dajs of our grandfathers. There has been nowe in connection with our own Nary; and there has been rery little in connection with forcign naries. There has been no real out-and-ont fighting like that of the old sca-dass, escept, perhaps, a little the Americans lind in their recent civil war. So that the conduct of a modern sca-figlt is entirels a hypothetical subject, which one can only speculato upon as an interesting problem, full of' unknown quantitics. As an old gunnery Ofiecr, I long ajo came to the canclusion that steam mas against the gunners, fatal to the guns, fatal to accuracs of fire, bectuse of the fatal faicility with which the helm can be used simply to manceurre, without reference to tho guns and gunners. I have often felt, as a gunuers Officer, that the dajs of guus as a truly offensire weapon were numbered. If we went into action now with other narics, that are cqually skifful and equalls coumgeous as our own, and equalls re:tly to join in action, the first attempt, I think, on both sides would necessarily bo to use the guns. But when wo are told, as I understand from the paper, that the "MLonarch," can ouly mako one hit erers four minutes, so that in the course of forty minutes sho would only make ten hits at rarious angles, with hardly ans penetra. tions, patience on both sides would soon bo exhausted under that process, and both mould necessarily bo driren to ram. If that is the case, then, crery ship, large and small, ouglit to be fortified and strengthened in the bors for the purpose of ramming, sloould tho opportunity arise. I hare always, thought that thero would be rery great diffeulty in ramming at a rital angle; but; as the lecturer went on, ho shook my idcas of the diffeulty of a ram striking another ressel, though I still think experience and skill and nerre rould alone accomplish it. What shook mo most was the account of the experiments eo practically conducted by the Russians, under the guidance of the first seaman of the day, Admiral Boutakor, in which it appeared that striking with the ram was a certainty. It appears, then, to bo an established fact that one of the ressels cin ram the other at the eud of a certain number of minutes. That fact has sliaken ms secpticism as to ramming. But if those Russinn ressels had not onl5 acted as rams, but had been prorided with guns, and also with torpedoes, ther would not hiro passed ono another so frequently in the cffort to ram without inilicting injury with thcir guns, or without bringing thcir torpedoes into destructiro contact with ono another. That brings mo to another point. If tho torpeclo were to come into $u s e$ in conjunction in the same ship with the ram and with the guns, it rould restrain the indiscriminate use of the ram; for just as the ram supplauts the gun, so the torpedo will supplant the ram, as it rould be dificult and dangerous to approach a ressel for tho purpose of ramming, which wns bristling with torpedocs all round. The gun mould then come into requisition to protect both the ram and the torpedo. The conclusion I come to is, not to build special resecls for any one arm, but that erers ship should be armed with all threo weapous, to bo used as opportunity offers. These are the changes which are coming in future combats, and thes must be met bj corresponding changes in our ships. I understand that Sir George Sartorius, whose opinion we should nll defer to, thinks lie can aroid tho torpedo when he is ramming; but I should not like to come into close quarters with a resscl that was bristling all round with torpedocs. That is a point upon which I should be glad to hear tho opinion of the Ollecrs present, who aro better gualified than myself to gire an opinion.

Commander A. II. GiLsrore, R.N.: I came here prepared to hear a lecture on manceurring flects, nnd Captain Colomb has giren us a lecturo on a trial of skill between two riral Captains in command of rams instead. Isuppose they are to be either broxdside ships or turret ships. I think in the caso of ramming, the turret ehip has a great adrantage orer the brosdsido ship. She has merely to be kept endon, and she has the usc of her cnd-on fire, to which the other ressel must expose her broadside before she can reply. I was with Captain Dawson some Jcars ago, at the first trial of Captain IIarrç's torpedo. No ressel rould attempt to ram another that had the use of these torpedocs, unless she was fitted up on the cellular sgstem. 
Fio cioubt those Russian offecrs, when trying to ram one another with gunboats, were under no idea of coming to any great gricf. Their nerres were quite steads; they had merely to get their stem on ono nnother's ressel if they could, and, protected as theso experimental gumboats were, without danger. But, as Captain Colomb says, a few sceonds here, a few eceonds there, in caleulatine tho time, a turn ahead of the screw nore or lcss, must. make it almost impossible for ressels to meet at. an effectire ramming angle. Then $I$ think the powrer of the gun must hare a great influence upon the ressel being attacked. For instance, $x$ means to ram $y$. $x$ being unarmed, merely a ram, $y$, bringing the whole foree of her artillery to wrork, must do a great deal of damage to $x$. I think also the present system of guns will bear no comparison with Cuptain Irarrey's torpedocs. I know no Officer in command of a ship that dare approach a torpedo resscl. All you mant is a small ressel of high epeed, belted round the water line, and decked orer, ns tho Irish dispatch ressels are, with a rise in her deck, and tho shot rould glance off. She is perfectly impregunble to the licariest sliot of auy gun, and would herself destroy an enemy with perfect case.

Captain Goodexoran, R.N.: I think Captain Colomb, in his rery euggestire paper, has giren the rery best plea that could be giren for the intenso study of theso subjects. For, as it has becn said that boldacss, and nothing but boldncss, will carry the day in war, so I think you ean say that nothing but intelligent study of our profession in time of peace will prepare us for the derelopment of that boldness at the proper time. In no case is that more strongly shown than in this system of attacks by ram, where boldness will bo the neccssary accompaniment of intelli. gence. Because, after all, you may conceire a number of imaginary positions of ships, and imaginary forces and specds of (ships, and ron may draw a number of combinations of those ships' morements upon paper, and jet at last the ramming blow will be struck by the boldness and stomach of the Commander of one of them. I was rery much struck with what was said by Captain Vansittart when he was in the Channel Squadron. Being asked his opinion on ramming, he said, tho first thing neecssary in an Offeer who was going to ram was that he should hare a good stomnch and a good digestion. There cannot be anj doubt about it; because in crery ease in which the ships aro brought together, if they are ships of equal specd and equal turning porrers, an excess of correctness of ese, of judgment, and boldness ou the part of ono mau mill in an instant decide the engagement. There are one or two points in the lecture to which I should liko to adrert. The first is on tho general remarks which preceded Captain Colonb's lecture. II drams attention to the necessity of opinions being formed on this subject, in order that our ships might hereafter be properly desigacl. There can bo no question as to the rery great necessity of this. There was one thing said with regard to guns which I think Captain Colomb might correct a littlc. It is the experiment in Vigo Bay. Ifis deduction from that experiment hes been most careful, and ho has rather orerstated than understated the porrer of the gun; but in ono place loe stated that the number of the rounds fired from the $2 \overline{\mathrm{v}}$-ton gun was one in two minutes; in another place, that it was one in three minutes. The Vigo esperiment mas this-that with tho guns of cach ship all loaded, a signal was mado to commence firing at a large rock. Therefore, the guns were fired at the rery instant the signal was giren to "commence." The result was that the "Ircredles" fircd about four rounds per gun in fire minutes; tho "Monarel." and the "Captain" fircd about threo rounds per gun. Therefore, in estimating the number of rounds, you should subtract ono round, or once the riumber of guns, in maling the calculation. It would, therefore, appear that the guns were not fired so rapidly as Captain Colomb has said. That would make $\mathrm{a}$ difference in furour of his argument. Then, we come to the comprarison of tho "Mronareh" and tho "IIcreules," a comparison which has been followed out still further in the general obscrrations as to the turret and tho broadside ship. I am not sure whetler Captain Colomb rished to state the question in this way, and I would ask lim in lis reply to put it more clearly, whether he would consider tho "Monarch" as a broadsido ship carrying her guns in turrets, or mhether lio considcrs the "Nonarch" as a ressel apart from the "Irereules," as a true turret ship. Becauso that is mhat the "IIonarch" seems to me to be. There is no reason, for instance, why, under the forecastle of the "Mronarch," wo ghould not put guns (sup: 
posing sho lind now a forecastle big enough to carry them), of equal porrer with the guns under the forecastle of the "IIercules." Therefore, it secms to me, it would be more distinct and more definite, and it would lead to more scientific argument, if tho "IIonarch" was to be defined as a broadside ship carrging her gums in turrets, learing the appellation of "turret ship," or some other definition, to express clearly 2 ressel that las a fire from her lieariest guns all round, in line of $\mathrm{kcel}$, alead, all round on cither side, nnd tery nearly in line of kecl astern. In that casc I am doubtful whether Captain Colomb would still stick to the broadside ship, pure and simple, or the broadside slip carrsing ler guns in turrets, when the former lias so linited an arc of fire as $70^{2}$, viz., $35^{\circ}$ before and $3 \overline{5}^{\circ}$ nbaft the beam. Passing now from the guns to tho diagrams, and to the part of the lecture which deals with ramming, and which Captain Colomb has so clearly set forth, I think he cnters upon tho argument with an admirable proposition, nomely, that a ship adrancing at speed has two circles on either side of her, within which she cannot possibly placo herself. That is an expression which gires a rery concise riew of the state of affairs. Going now to Figs. 4, 5, and 6, the rcry arguments which he has used, and tho diagram which ho has drain, lead me, contrary to his opinion, to have a rers strong fecling in firour of end-on firc, which I rould not limit to a fire simply in line of beel, but which $I$ should describe as a fire uninterrupted in line of keel from some points on one side of the bow to some points on the other side of the bow. If the fire was simply end-on in line of keel, with reiry fer degrees on either side, I think it would bo rery inoperative, and not worth the price which jou must pay for it. But the fire round the bow is to me of the greatest ralue, because, looking at Fig. 4, it scems to me that the rers great adrantage which $x$ has there-it has been well pointed out by Captain Colomb-is, that $y$ is more nearly in the line of $x^{\prime}$ 'seel than $x$ is in the line of $y$ 's $\mathrm{kecl}$; and that whenerer $x$ quits that positiou and turus amay from $y$, she at once gires $y$ the position of adrantage which Captain Colomb has pointed out, and has so fully drrelt ou. Now, supposing that the ships are not trarelling towards each other at so wide an angle as a 4-point bearing, but trarelling moro nearls towards each other, the nearer $y$ points towards $x$, the nearer must $x$ point her bows towards $y$, if she wishes to aroid all danger of $y$ getting withim her circle. Take, again Hig. 5 ; there the rery same thing, I think, is shomn. Directly one ressel turns the least away from the other, she at once places herself in a position of disadrantage, unless sho has something to make up for it, either speed, or turning power, or better stomach or ese in the body of the man who commands her. That is a point, that of meeting straight end-on, which I think requires to be rery well looked into, and about which ererybody who has to command a ship should thoroughly make up his mind; because that seems to me a position in which ships will again and again find themsclres, pointing directly to their adrersaries, and the first Commander who dinches, no matter from what cause, cither from want of stomach or from want of eje, will put limself at a disadrantage. Other things being equal, he may recorer himself, but once he has flinched, once he has slackened his speed, ho has put himself into a position of disadrantage, that is to say unless ho knows and allows for his opponent's state of mind and intentions. Ono can hardly follow out tho arguments on Fig. 5, unlcss one imagines an adrantage on one side or the other, but, supposing the ships to bo equal in all other respects if thes meet, the adrantage will be to the ship that is most strongly built. In all the other points of bearing in which ships aro supposed to approach each other, there is one thing which secens to be esseutial, and which, I think, it will be well for ererybody to beep his mind upon, that is, the importance of improring our compasses. I do. not sce any prospect of a ship being ablo to manourre with success, to approach his adrersary in such a manner as to gire the decisire blow, unless the Commander is ablo very niecly to estimate both the line that he himself is proceding on, and the line that his opponent is proceding on. 'To to this, if jou are in an open sea, you : must have the assistance cither of rery accurate compasses, or you must be in a potition near to land, where some objects on the horizon are distinctly marked out, and by the transit of your opponent past those objects you may estimate pretty well what he is doing, the rate at which he is unoving, and how you may best hit him. I remember that when the Channel Squadron was entering Gibraltar there was rather an expectation on board one of the ships dịring 
the erolution in which the lines were crossing cach other, of tro ships coming in collision. But I beliere the fact was that tho person who was conning the ship that was supposed to bring the other into danger had the opposite shore in riew the whole time, with a perfect lnowledge of all that was going to pass, and that ho placed his ship exactly whero ho meant to place lier. That was entirels duo to tho shore being in sight, and to the transit of the other ship past the points of tho land being easily obserrable. To bo able to do the same hind of thing in the open sea, sou must lave rery accurately graduated, sensitirely moring, and at tho samo timo very steady compasses. Theso are rery diffcult things to get in ono compass, but it is rery desirablo to hine them, aud it is rers desirable that we should keep that rery important object in rieir. There is ono other point in which I eutirely agree with Captain Colomb, that is the adrisability of haring high turning powers in our ships, to a certain extent that must bo superior to the adrantage of high specd. But thoro is an equation between tho two to be arrired at. Anjbody who can giro uj such an equation will confer the highest benchit on tho scrvice. It is to bo arrired at by calculation and experiment, but $I \mathrm{am}$ afraid ro are not in a position to arrire at it set. I should not like to sit domn without saying how much wo ought to scek for opportunitics to perform such experiments as the Russians hare been making in the Baltic for some years. Those experiments are of incalculable ralue; if wo cannot perform them in our big ships we must try by united representations to get them performed with gunboats, and; if we cannot haro gunboats, then with nodels on tho table. Whaterer wo can do towards ascertaining the powers of equal ships at equal speeds in combat I think we are bound to do for ourselres.

Captain Hanter Grusone: Captain Goodenough made a remark about the desirability of haring good compasses in our ships. I do not know rhether jou havo seen Iord Caithness's compass, which is the most perfect ono that was over made. The oscillation is reduced to a minimum, and the heariest guns can bo fired without making the compass spin round, as compasses do.now when heary guns aro fircd. It the same time it is rers sensitire and good in erery respect.

Captain ARTIror: It is uscless for four or fire degrecs of rolling, the friction is so rers great.

Captain MIoscriefF : In making ono or two remarks upon this subject, I shall confine myself entirely to that part of it relating to guns. It may interest this mecting to hear a statement connected with the application of a new system of mounting artillery in ships which I haro brought forward. Captain Colomb has alluded to the relatire decrease in porrer of guns in ressels. The ner system will hare a tendeney to restore that power. This draming represents a ressel of the "Derastation" class, which I take for example, and we will suppose that this is a plan of the deck. Tho centre part, or breastwork, is placed somemhat in this manner. These ressels aro intended to carry two turrets with four 35-ton guns. The statement which I wish to make is this, that in place of these turrets with four guns, six 35-ton guns can be mounted upon the new hrdropneumatic earriages, with the following extraordinary results, that thereby you hare increased the armament of theso ressels, and jet learo a largo margin of weight to be disposed of, or clse the size of the ressel can bo reduced for the samo armament. With the MIonerieff arrangement in place of tho turrets, firo guns firo to the front in line of kecl, and sir on either broadside, tho funnel, engine, rentilators, and boats being in the middle, as with the turrets. Iou will obscrre in this case that, taking the threo bor guns, tho centro oue is only capable of firing on the samo conditions as the turret, that is to say, with it you cannot firo with any great depression, on account of tho borr. But if the ressel is a little cut amay the other tro gans can firo straight forward, and jet-haro a good many degrees depression; not only, horrerer, can theso guns firo to the front, but also two of tho stern guns alternately, which makes fire guns on lino of keel; there is no turret in the way, you can, thercforc, firo straight orer tho front guns. The Lorizontal port eloses by the recoil, so that the heaviest charges can be fired orer the heads of the men by another gun in rear of them, without either inconrenience or danger. Again, on the broadside you can fire four guns with masimum depression, and two with small depression on one side, or six guns on either broadside. If this arrangement is adopted for tle "Derastation" two more guns are thereby obtained, but I maintain at the same time that much greater power than one-half more is got, 
bceauso I belicro it is acknowledgec both by naral men nnd artillerjmen, that tho twin guns in turrets (putting aside tho inconrenience of muzzle-piroting) hare not the samo power as gums acting indiridually; thes aruobliged both to bein the samo line at all timcs, and, of course, if a turret is disabled tro guns aro disabled by ono accident. Therefore, this arrangement of sir guns, instcad of four guns, gires an increase greater than at first appears, and, moreorer, leares a margin of a rery largo nmount of tonnage to be disposed of cither for carrying a larger quantity of fucl, or for increasing the armour. I hope that this statement, which you will find to bo correct, rill not bo considered forcign to tho snbject beforo the mecting.

Captain SCOTr, R.N.: I think this is a rery important subject, requiring much careful considcration. I followed with a great deal of pleasuro the clear statement in which Captain Colomb elescribed the ramming process. But it seems to me that ho has giren too great prominenco to it. Wo hare heard just now from other speakers of the importance of tlic torpedo, and of the probability that it. will greatly interfere with successful ramning. If that should bo the case, it must again bring the gun into its old place; but $I$ am rery far from admitting what Captain Colonb says as to tho decreased ralue of tho gun; I do not think it will bo found at all to bo what he imagines in actual practice. II s2ys the gun los receded, and has drawn up a table to prore this. I think if you go moro closcly into the matter it rill be found that the gun has not receded. Wo hare placed rery heary plates on the sides of our ships, but theso plates are borne upon light bottoins, and at present wo do not know what will be the cfiect of hitting them. From what I hare seen at Shocburgness, and haring afterwards considered the subject rery carefully, it appears to me rery doubtful whether under fire these plates will remain long on the side of a ship. If the plates como off, the ship will get a hecl and be liable to attrick on the wreak parts which wrere previously under watcr. Eren supposing you do not knock of portious of tho armour, there will be a great deal of plunging and other fire, whicls will strile the ship rery often in parts that are rulnemable. Ships do not always kecp upright, but will bo hit frequentls mlicn hecling orer. As far as accuracy goes, I think steam has tended to very much increase it. At the present timo we liare rers for relcrant experiments, and our men aro not well drilled, consequently aro not on a par with the reapons they aro ealled upon to use. But, liercafter, we may look for much greater accur:es of firo than me now obtain. The subject, howerer, has so many aspects that it is most difficult to draw the line between tho rclatiro ralue of the clifferent reapons. It scems to me that to place the ralue of onc weapon prominently before that of the other is a mistake, for all should be mado as perfest as possiblo to mect the rarging circumstances of warfare. Doubtless ramming will bo the first mode of attack; that is, squadrons and ressels, if they are porrerful cnough to ram with adrantage, will cndearour to do so. The gun will also hold just as important a vosition as it has crer done; and tho torpedo will supplement the gun, and be a rery effectire mcapon. With regard to the light resscls spoken of by Captain Colomb, if yon hare a resscl of 1,000 tons, how arc you to iron-plate lier, or eren put an armoured belt round her, and gire her specd? Fou cannot efficiently armour-plate a small ressel, and in merely giring her a belt round the water-lino you expose her to be shot through sicles and bottom from abore the belt by a larger ressel. Again, with regard to the ramming, I think the proper way to uso the ram is to adrance end-on, and then the henrier ressel would enteh and sink tho lighter one, therefore I clo not hold with the idea of building small ressels in licu of largo ressels. I think small resscls will be found not only unsuited for rams, but for the gencral serrices of our Nary. Englancl is strong, but England's strength depends upon her long arm and ler powers of offence. She nust hare ressels that can go to all parts of the glole, and can carry largo quantities of coal, with heary guns and large numbers of men. We cannot put large numbers of men, heary guns, powerful engines, and largo quantitics of fucl into small ressels. Therefore large resscls aro a necessity; large ressels will be the moro porerful rams; large ressels mill gire a better means for firing the torpedo, and will also giro the best platform, not only for the heary gums, but also for the smaller guns, which must supplement them.

Commander II. W. BrExr, R.N.: I think Captain Colomb's data requiro cramination, and to cramino them they siould be carefully read, and corrected if needs 
bc. Tho subject rauts $n$ great deal of study beforo wo cen discuss it. I must content mssclf with one or two remarks, hivin had the pleasure and benefit of discussing wilh Captain Colomb the battle of Lissa nung ycars ago, when he held that guns were getting to a minimum of use. When I wis serring aflont I took notice of firing when practising at a target, and found that we liad tho greatest difliculty in kecping the target in riew, owing to the emoke of the gun; and I camo to the conclusion that the smolo of the guns would bo a nuisance to you in conning the ship, and that therefore you-would fire but little. I found in tho "Escellent" thoy wero teaching ship's coimpanies to fire rery little in action. They were teaching them in this was, that the men should bo so quict at quarters that they would stand steady under all circumstances, and they were looking round for mechanical means to firo all tho guns together. They had an elcetric ejstem; and I see in tho "IIonarch" they hare a mechanical sjstem by which they fro tho guns together. It appeared to me thes wero seeking for some meaus by which one person might fire all the gruns together. With the men being taught to be quict and the annoyance of the smoke of the guns, I arrired at the conclusion that you would fire them in action rery little, only in passing your opponent, aud that the ram would bo Jour best weapon of offence. Espressing my opiniou on the subject, I was told that the end-on fire vas ercrsthing, that the end-on fire was the most useful of all. Wo lad tro bow guns in the ship I was in, and fring at a target, I found their smoke was more annoying than that from bioadsido guns when they wore fired, and it was more diffeult to kcep the ship on the tar ret. Therefore it appeared to me that the only time to fire bow guns would be when using rour ram as you touch your opponent, aud at no other time rould you fire them, because they would be such a nuisaneo to you. Afterwards it was my fortune to sce how IIarrey's torpedoes were used. From tho first, when I saw them, it secmed to me that we lind got something that would frighten us from ramming. I quite agree with Captain Dawson that it would be a rery dangerous thing to try to ram a ship if you found her bristling with torpedoes. Of course you might miss a ship, and to miss a ship with a torpedo astern would be ccrtain death to Jourself. At present it is rery diffeult to say where we are; we do not know; we aro all abroad. Therefore $I$ wish this diseussion had been postponed, that peoplo might have had tho opportunity of stud ring this paper of Captain Colomb's. It is of such rital importanee that it requires rery careful looling into. As to the experinents that hare been tricd in the Baltic by the Russians, I think the same thing ought to be tried in tho Solent by oursclres. Oftiecrs of all classes on laxlf-pay would only be too glad to take part in them; it would teach then so much. I hope the mention of those experiments in Captrin Colomb's paper will be the thin elgo of the wedgo that will cause us to hare experimental ramming, and experimental attack and defence with our ships.

Captain WILEster: Will you nllow me to suggest that tho crperinents aight bo carried out with the steam launches of thoso ship3 that hare stcam launches.

Admiral of the Fleet Sir Gronge Sartones : As Captain Colomb has been kind cnough to allude to me in a complimentary manner on a subject in which I hare taken a great deal of interest, I should wish to say a few roords in reply; but as I am confined to ten minutes, I can touch only very slightly on the matter. I hare long adrocated the ram is the re-introduction of the ancicnt mode of fighting. It struck me that the use of stem as a motire power would en:ablu us to use the rim with considerably greater efliciency and cliect than the ancients could hare arrired at. Since 1855 and 1856 my nttention was more particularly drawn to this mode of attack. Without entering into detail, I rould simply cuumerate the conditions and circumstances under which the ram can bo of the greatest service, and show its power and greatest effect orer erery other class of ressel. I will suppose a squadron of cighteen or tirenty of tho finest ressels that can bo got, whether from Russia, Frauce, or England; let thero be one ram without a gun, without any armourplating, but very rapid, and rery handy, witl much more speed, of course, than any of the ressels that she is going to attack; that this ressel has coal on board which will not emit smoke, when she accompanics this largo flect. Iy her superior spect sho can almays aroid an action when it is conrenient to ler, and sho can make her attack when it pleases her. Granting mo those two points, sho necompanies thia 
equadron, tako for instance, of trenty ressels. The night is dark; tho ram carries a hind of jury mast, which sho lowers down; she is low in the water; she secs erery one of the larger ressels that she is accompanjing by thcir high hulls, tall masts, and funnels; she runs down at the rato of ten or twelre bnots upon any one of the ressels that sho has firel upon. I will now ask any sailor; here is a ram running domn at night on tho resscl that sho is going to attack; sho makes uso of a fuel that emits no smoke; she lias lowered down her masts; she is not secul until alnost the very moment when tho look-out man calls out, "The enemy is upon us," which can bo but a rery fer ecconds; how is it possible for any of these largo ressels, particularly largo broadsido ships, by any action of the helm to aroid the ram in so short a time? Eren if the ressel attacked is able to firo two or three guns, a ressel at night with a narrow bow presented to the brondside ship she is going to attack, how is sho to bo ecen? Sho is moro likely to bo felt before she is scen. What is tho chanco of her being hit? To supposo in war that jou are to be so perfectly protected that no shot can penetrate, that there is no lifo that can be lost-in-something like the iron boxes wo now mako which are perfectly sccure, but these can do rery little mischief to the cnemy-how can their guns be fired with any chance of hitting this ram before the latter garo the blow? It is impossible she can fail in doing that becauso thero is nothing to disturb her; she fircs no gun ; there is no smoke to confuse her or bother her; sho gires the blow, and the blow that is giren with the forco of sixty or secenty thousand tons, what ressel can resist that blow? Jir. Reed, who was one of my first opponents in 1855 and 1850 , in his pamplet adnits that there has been nothing inrented by human genius that has tho power of the ram for naral purposes. I admit that the turret will be a moro formidable enemy to tho ram than broadside resscls. But at night the turret resscl has no time to fire with any chance of success. Then, again, suppose Spithead full of ships, as it was at the rerien; what is to prerent a ram coming in at niglit into Spithearl or at daybreak, and running through the ships at anchor, hitting awny right and left? What chance is there of a battery striking her when she is anoug the shipping? What battery can firo upon the ram without striking moro friends than encmics? There are only two cases out of many where the ram has an enormous adrantage orer a rery large number of the most porrerful ressels that can bo built by any nation. In a single action, of course, it is moro diffeult. Tho only point upon nich I rather disagrec from Captain Colomb is, that for the unarmed ram I think extreme speed and extreme handiness are indispensable. But these qualities are equally inportant for an armed ram. I adrocate threo classes of mins. But to show the special power of the ram as a ram, I shall coutent mysclf with quoting the case of the unarmed ran. These resscls can also carry much more fuel. Therefore, from the circumstanee of being accompanicd by $n$ ressel of this kind which is able to carrs a much larger quantity of fucl, and to make feints, the ressels of a squadron that are liable to be attacked by her, these ressels will be constantly kecping up full steam; and in the course of a rery few days they will be lost from want of steam. Then it is a stern cliase, by tho ram haring speed, her tactics mill bo to get under tho stern and to destros the steerage-gear of the slip she is going to attack, then she can delirer her blow with perfect safety. With regard to Captain Darson's obserratious about the torpedo, I think tho ram can bo a torpedo resse? as well. Therefore, without entering into other details as to tho expedients by rhich the nttack of tho torpedo might be very easily orercomo or evadecl-this is, howerer, not the time or occasion to enter into that question-I simply repeat it is undeniable that the ram can be a most effectivo torpedo ressel and a ram, also equally effectirc.

The Crarrisar: Perhaps Captain Colomb will now reply to the obserrations that hare been made.

Captain Cososn : There is not mucls for me to Eay, in reply. Captain Dawson expressed his opinion that the torpedo lias now becomo the lending weapon, haring taken, in point of fact, the ground that was occupied by tho ram. I agree with that to a certain estent. Captain Scott spoke in the same strain. I had already met the opinion of both these Olifeers in this paragraph :-

"Whererer the IIarrey torpedo makes its appearance, whether in company with "guns and rams, or by itself, it is etill speel which must carry the day. Whether" "t oue ship determines to ue his gums or his ram, he must, try his syeed and his 
"torpedo, if the other chooses" to adopt that mode of attack. $y$ could not, as in "Fig. 2, diagram III, turn towards $x$, and allow hin to crosi his bows: he must " turu away from him, and trust to his own torpedo to kcep $x$ 's ram clear of him. " Inenec they como to parallel conrses, and artillery fire, broadside to broadside. The "strugrgle will immediately be, which is to lead the other, and whicherer can suc" ceed must bo rictorious. Tho tendency of the Harrey torpedo secms thus to " be, to bring the gun forward again, as the tendency of the ram has been to push it " back. Whilo this struggle for precedeuce continues between two torpedo ressels " at short range, much damage must be done bj artillers; and if the speed of tho

" ships is acarly equal, the combat might bo decided by a broadside action of the "old type, cxeept that it is carricd on at high speed."

Captain Goodenougl required some explauntion as to an carly statement in my paper with regard to the firing of the "IIonarch." "In tho first part of my paper I said one round in three minutes could be fired, whereas afterwards I quoted it as being ono round in two minutes. The lustors of tho anomaly is, that in tho first instance I quoted the opinion afloat as to what the rapidity of fire would bo in action. Afterwards I corrected that opinion by clata, in order not to be too liard upon the guns; in point of fact, I garo them the full benefit of any doubt that might crist on the question, and cut an extra minute off, because it is possiblo to fire one round in two minutes-conscquently, I allowed that it would be so. I do not quite understand Captain Goodenough's remark in reference to the "Monareh " and the "Hercules," and the nethod of considering the end-on fire. But I do not think I need go into it, becauso I only spoke of those tro ehips as rams combined with guns. If argument only gocs so fas as to say, that if you are to make the ram your superior weapon, then you do not care for a large are of fire, and you do not care so much for end-on firc. If, on the contrary, you are determined not to use the ram as your meapon at all, then jou come to a totally different state of affairs; then you require a large are of fire; then you como to the position giren to $y$ in Fig. 5 , dingram I, because she docs not mean to use her ram, but her guns, and she meens to uso tho latter in peace and quietness while the other uses lier ram. She does that by bringing her adrersary end-on. Captain Scott alluded to tho nso of light ressels and the possibility of destrosing them. But jou cannot destroy light resscls with a few licary guns, the number of fired shot will be so small. To attack a light ressel, jou must provido yoursclf with a largo number of light guns, as rell as leary guns, in orler to gire rapidity of fire, in order to gire a fair proportion of hits on jour object.

The Crumses: : I think we must all hare arrired at one conclusion on this occasion, that of beine rers much obliged to tho lectures for tho lucid manner in which he has brought the subject under our consideration, and for having brought out tho discussion we havo listened to. A subject of this magnitude must produce great differences of opinion. We have leard some expressed here to-night. The object is to set men's minds thinking, and in the interim betreen this and another lecture in continuation of tho same subject, wo shall be, perlaps, better prepared to cnter into the merits of the subject in all its bearings. This, howerer, will not detract from the thanks that are duc to Captain Colomb on the present occasion. 